\title{
A Molecular Hybridization Approach for the Design of Potent, Highly Selective, and Brain-Penetrant $\mathrm{N}$-Myristoyltransferase Inhibitors
}

Justin R. Harrison, Stephen Brand, Victoria Smith, David A. Robinson, ${ }^{\circledR}$ Stephen Thompson, Alasdair Smith, Kenneth Davies, Ngai Mok, Leah S. Torrie, Iain Collie, Irene Hallyburton, Suzanne Norval, Frederick R. C. Simeons, Laste Stojanovski, Julie A. Frearson, Ruth Brenk, Paul G. Wyatt, ${ }^{(\infty)}$ Ian H. Gilbert, ${ }^{*}$ a and Kevin D. Read*(i)

Drug Discovery Unit, Wellcome Centre for Anti-Infectives Research, Division of Biological Chemistry and Drug Discovery, School of Life Sciences, University of Dundee, Dundee, DD1 5EH, United Kingdom

Supporting Information
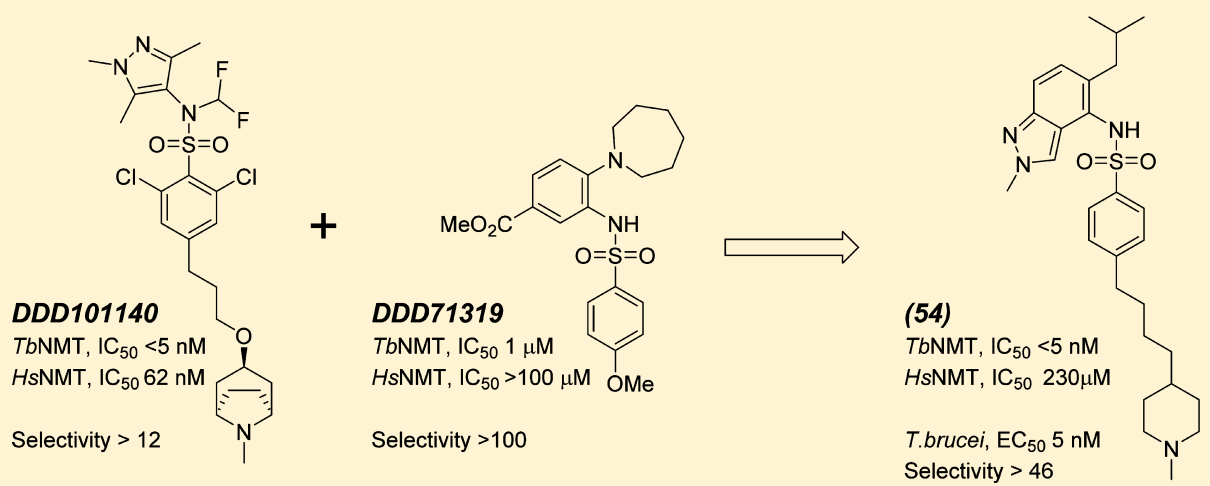

ABSTRACT: Crystallography has guided the hybridization of two series of Trypanosoma brucei N-myristoyltransferase (NMT) inhibitors, leading to a novel highly selective series. The effect of combining the selectivity enhancing elements from two pharmacophores is shown to be additive and has led to compounds that have greater than 1000-fold selectivity for TbNMT vs $H s$ NMT. Further optimization of the hybrid series has identified compounds with significant trypanocidal activity capable of crossing the blood-brain barrier. By using CF-1 mdrla deficient mice, we were able to demonstrate full cures in vivo in a mouse model of stage 2 African sleeping sickness. This and previous work provides very strong validation for NMT as a drug target for human African trypanosomiasis in both the peripheral and central nervous system stages of disease.

\section{INTRODUCTION}

Human African trypanosomiasis (HAT), or sleeping sickness, is caused by two different subspecies of the protozoan parasite Trypanosoma brucei: T.b. gambiense and T.b. rhodensiense. The disease, which is fatal unless treated, is transmitted by the bite of an infected tsetse fly. It has two stages: an initial peripheral infection during which the parasites are found in the bloodstream, giving rise to nonspecific symptoms, and a second stage when the parasites enter the central nervous system, causing the classic symptoms of HAT, eventually leading to coma and death. Currently, there are five treatments available, although none of them are satisfactory due to toxicity, treatment failures, or the requirement for parenteral administration, which is inappropriate in a rural African setting. ${ }^{1}$

$\mathrm{N}$-Myristoyltransferase (NMT) represents a potential drug target for HAT because in T. brucei RNAi knockdown of NMT has been shown to cause cidality in cell culture and to abrogate infectivity in several animal models. ${ }^{2,3}$ We have also reported the successful chemical validation of TbNMT using the prototype NMT inhibitor DDD85646 (2) derived from pyrazole sulfonamide screening hit DDD64558 (1) (Scheme $1)$, which is highly effective at curing mouse models of hemolymphatic (peripheral) infection., ${ }^{4,5}$ Unfortunately, we were not able to obtain conclusive evidence for $T b \mathrm{NMT}$ validation in stage 2 disease as the blood-brain barrier penetrant compounds we developed did not have a sufficient therapeutic window. ${ }^{6}$

Several research groups have also interrogated NMT as a potential target for the treatment of leishmaniasis, ${ }^{7,8}$ malaria, ${ }^{9}$ fungal infections, and cancer. ${ }^{10-21}$ In most/all of these inhibitors, there is a basic center in the compound that maintains a key interaction with the C-terminal carboxylic acid, found in the peptide binding site of NMT.

Received: June 4, 2018

Published: September 12, 2018 
Scheme 1. Pyrazole Sulfonamide NMT Inhibitors ( $S$ " = HsNMT IC $\mathrm{I0}_{50} / T$. brucei $\left.\mathrm{EC}_{50}\right)$ : DDD64558 (1), ${ }^{5}$ DDD85646 (2), ${ }^{5}$ and DDD100097 (3)<smiles>COc1cc(C)c(S(=O)(=O)Nc2c(C)nn(C)c2C)c(C)c1C</smiles>

$D D D 64558(1)$

TbNMT, IC $\mathrm{C}_{50} 1.9 \mu \mathrm{M}$ HsNMT, IC ${ }_{50} 22 \mu \mathrm{M}$ T. brucei, $\mathrm{EC}_{50} 21 \mu \mathrm{M}$ $\mathrm{MRC}-5, \mathrm{EC}_{50} 55 \mu \mathrm{M}$ Enzyme Selectivity $=11$ "S" = 1

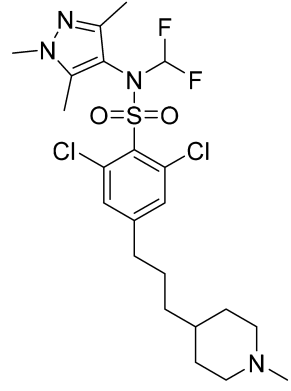

DDD100097 (3)

TbNMT, IC $500.002 \mu \mathrm{M}$

HsNMT, IC $5_{50} 0.012 \mu \mathrm{M}$

T. brucei, $\mathrm{EC}_{50} 0.001 \mu \mathrm{M}$

MRC-5, EC ${ }_{50} 1.0 \mu \mathrm{M}$

HepG2, EC $506 \mu \mathrm{M}$

Enzyme Selectivity $=6$

"S" = 12

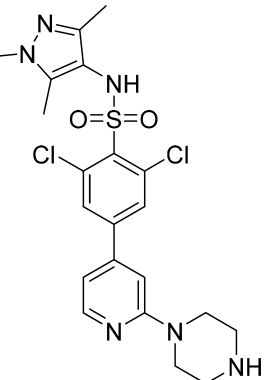

DDD85646 (2)

TbNMT, IC $500.002 \mu \mathrm{M}$

HsNMT, IC $50.003 \mu \mathrm{M}$

T. brucei, $\mathrm{EC}_{50} 0.002 \mu \mathrm{M}$

MRC-5, EC $500.3 \mu \mathrm{M}$

HepG2, EC $\mathrm{C}_{50} 5 \mu \mathrm{M}$

Enzyme Selectivity $~ 1.5$

"S" $=1.5$
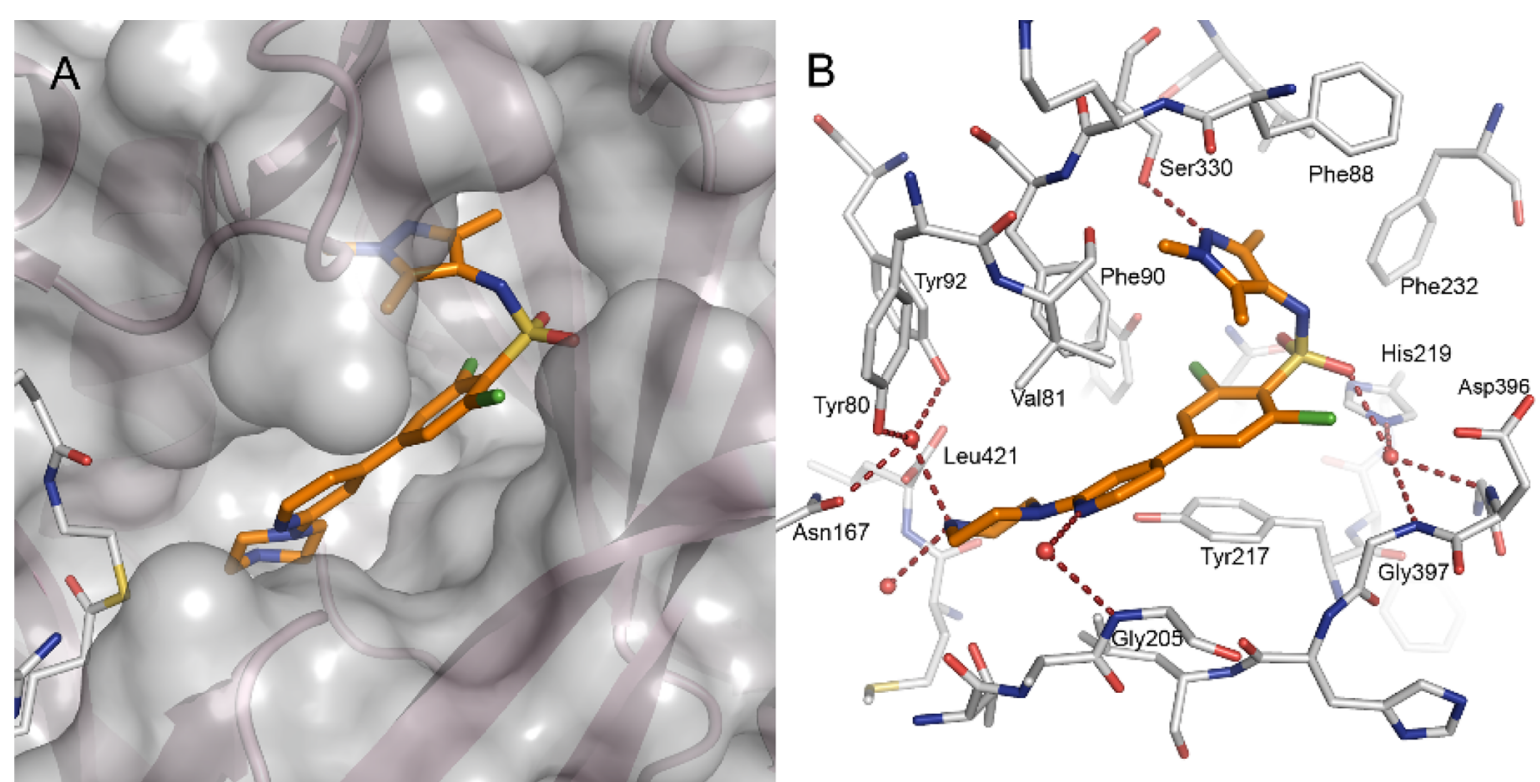

Figure 1. Structure of DDD85646 (2) bound to $\operatorname{LmNMT}$ (PDB ID: 2WSA). ${ }^{4}$ (A) DDD85646 (C atoms gold) bound in the peptide binding cleft. (B) H-bond interactions between the ligand and protein.

NMT catalyzes the cotranslational transfer of myristate from myristoyl-CoA to the N-terminal glycine of $\sim 60$ proteins; a modification that is implicated in localization and/or activation of the substrate-proteins. ${ }^{22}$ The enzyme operates via a $\mathrm{Bi}-\mathrm{Bi}$ mechanism in which it first binds myristoyl-CoA, causing a conformational rearrangement that subsequently reveals the peptide binding site. ${ }^{2}$ There is a significant deficit in our understanding of the identity of downstream targets of NMT in T. brucei; however, the ribosylation factors Arf and Arl have been shown to be NMT substrates important for survival of the parasite in cell culture. ${ }^{23}$

Attempts to crystallize TbNMT have been unsuccessful to date. However, we were able to obtain a structure for Leishmania major NMT ( $L m \mathrm{NMT}$ ), which we have used as a surrogate model for TbNMT (Figure 1A). LmNMT is the closest homologue of $\mathrm{TbNMT}$ for which a crystal structure has been elucidated: the primary sequence id was $74 \%$ identical overall and 94\% identical within the ligand binding cavities. Structural analysis was carried out on selected pyrazole sulfonamide ligands and has been previously described in detail. ${ }^{4,5}$ The ligands occupy the substrate binding groove of $L m N M T$ with the pyrazole occupying a pocket that binds residues 4 and 5 of the peptide substrate. The pyrazole nitrogen lone pair forms a key hydrogen bond with the side chain hydroxyl group of Ser330 (Figure 1B). The pyrazole $N$ methyl group interacts with the side chains of Val81 and the aromatic ring of Phe90, and consequently, larger substituents than methyl were not tolerated (Figure 1B). There was a degree of flexibility in the position and orientation of the sulfonamide group. For most ligands within the series, the 


\section{Scheme 2. Methyl Ester Hit and Close Analogues}<smiles>COc1ccc(S(=O)(=O)Nc2cc(C(C)=O)ccc2N2CCCCCC2)cc1</smiles>

\section{4} TbNMT, IC $\mathrm{I}_{50} 1 \mu \mathrm{M}$ HsNMT, IC $\mathrm{C}_{50}>100 \mu \mathrm{M}$ T. brucei, $\mathrm{EC}_{50} 12 \mu \mathrm{M}$ Enzyme Selectivity $>100$ "S" > 8.3<smiles>COc1ccc(S(=O)(=O)Nc2cc(C(=O)O)ccc2N2CCCCCC2)cc1</smiles>

\section{6} TbNMT, IC $\mathrm{C}_{50}>100 \mu \mathrm{M}$<smiles>CC(=O)c1ccc(N2CCCC2)c(NS(=O)(=O)c2ccc(Br)cc2)c1</smiles>

8

TbNMT, IC $\mathrm{I}_{50} 0.8 \mu \mathrm{M}$ HsNMT, IC $\mathrm{C}_{50}>100 \mu \mathrm{M}$ T. brucei, $\mathrm{EC}_{50} 21 \mu \mathrm{M}$ Enzyme Selectivity $>100$ "S" > 4.8

sulfonamide moiety hydrogen bonded through a highly coordinated water molecule to the side chain of His 219 and the backbone amides of Asp396 and Gly397. In other ligands (described elsewhere ${ }^{5}$ ), the water-bridged interaction with His 219 was replaced by a direct hydrogen bond between the sulfonamide oxygen and the side chain of Asn376. The aryl rings of DDD85646 (2) did not form directional interactions with the protein, though they stacked above the side chain of Tyr217, which lines the floor of the peptide binding site. Hydrophobic packing was increased further by the two chlorine atoms of compound 2, explaining their beneficial effect on potency.

Significant gains in potency were obtained by appending a basic functionality, which formed an ionic interaction with the carboxylate of the C-terminal residue (Leu421) and a series of water-mediated hydrogen bonds. In the case of 2 , this was obtained with a constrained amine, but it was subsequently shown that similar gains in potency could be obtained with a more flexible analogue such as DDD100097 (3) (Scheme 1). ${ }^{6}$

Lead optimization of the pyrazole sulfonamides subsequently led to the identification of potently trypanocidal brainpenetrant inhibitors, which were evaluated for efficacy in a stage 2 mouse model of HAT (e.g., DDD100097 (3)). ${ }^{6}$ Unfortunately, a fully curative dose regimen was not achieved due to dose-limiting toxicity. This toxicity is likely to be associated with the simultaneous blockade of host NMT (Mouse NMT is $98 \%$ identical to Human NMT ( $H s \mathrm{NMT})$ ), although it is conceivable that some as of yet unidentified action of the compound is causing the dose-limiting toxicity). Nonselective NMT inhibitors like compound 2 can be well tolerated at an efficacious dose to treat the first stage of HAT, a consequence of the high dependency of $T$. brucei on NMT. However, the higher doses often required to also effectively<smiles>COc1ccc(S(=O)(=O)Nc2cc(C(C)=O)ccc2N2CCCC2)cc1</smiles><smiles>CC(=O)c1cccc(NS(=O)(=O)c2ccc(Br)cc2)c1</smiles><smiles>COC(=O)c1ccc(N2CCCCC2)c(NS(=O)(=O)c2ccc(Br)cc2)c1</smiles>

treat the second CNS stage of the disease have been poorly tolerated, as was the case for compound 3, a blood-brain barrier penetrant compound. We therefore deliberately sought compounds with maximal selectivity to reduce the possibility of target-driven toxicity and provide a suitable therapeutic window to achieve a fully curative dose regimen for stage 2 HAT. In the case of the pyrazole sulfonamide series, we identified the subpocket around the Leu421 as an area in which we could obtain selectivity. Leu421 is the C-terminal residue of $T b N M T$ that interacts with the amine. We attempted to obtain an increase in selectivity by optimization of the amine but were only able to obtain a modest increase. ${ }^{6}$ We were unable to rationalize how to build in selectivity, and this was achieved empirically. At the time of carrying out this work, there was no human NMT structure available. Comparison of multiple parasitic and human NMT structures showed the active sites to be highly conserved with minimal evidence of conformational change; hence, there was no design rational to be drawn to generate ligands with higher degrees of selectivity.

\section{AIMS AND OBJECTIVES}

The overall aim of the research was to develop lead compounds with a profile suitable for delivering a fully curative, well-tolerated dose regimen in the stage 2 mouse model of HAT. In this article, we discuss the identification of a novel scaffold with selectivity for TbNMT over HsNMT. Structural information and our existing knowledge of NMT inhibitors was then used to increase potency in two new subseries. Further, we were also able to combine the separate selectivity-enhancing elements of our previously developed pyrazole sulfonamide series with those of this new series to 

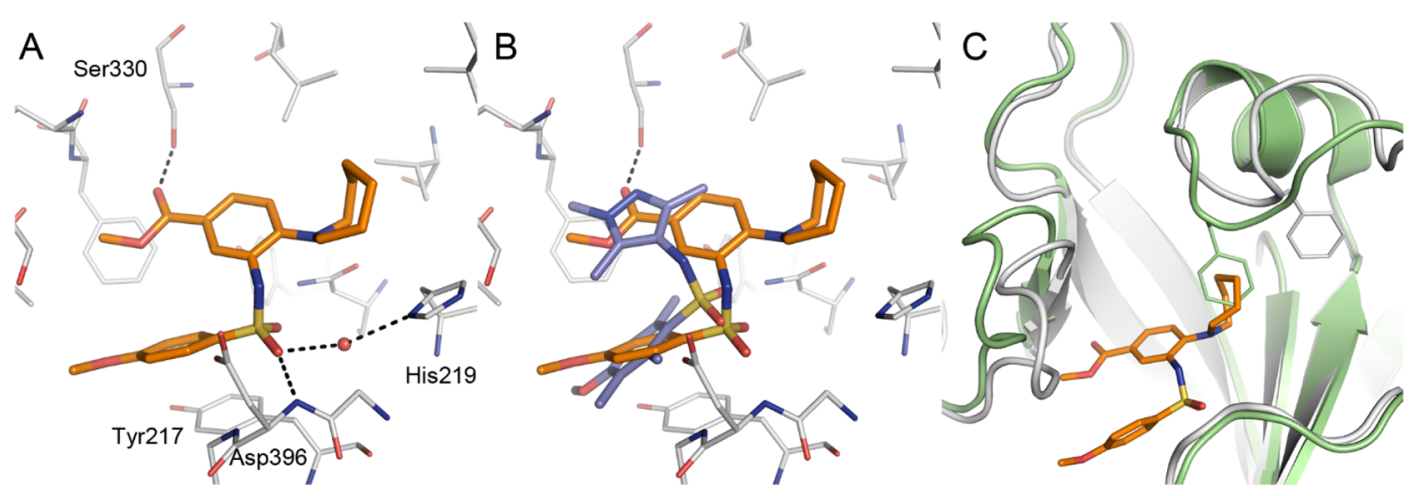

Figure 2. Crystal structure of $\mathbf{4}$ bound to LmNMT:MCoA showing key interactions. (A) Ester carbonyl forms H-bond to Ser330; sulfonamide oxygen forms H-bond to Asp396, and the lower phenyl ring stacks with Tyr217. (B) Binding mode of 4 (C atoms gold) compared to pyrazole sulfonamide 1 (C atoms purple) showing retention of the interaction with Ser330. (C) Conformational change in residues 231-236 (gray ribbon) induced by azepane ring of 4 (C atoms gold) compared to LmNMT:MCoA (green ribbon, PDB ID: 3H5Z). The side chain of Phe232 from each structure is shown in stick representation.

enhance the overall selectivity. We were also able to derive compounds with blood-brain barrier permeability.

RESULTS AND DISCUSSION

Identification of a TbNMT Selective Hit: Methyl Ester Series. Methyl ester 4 (Scheme 2), identified as a singleton by

\section{Scheme 3}

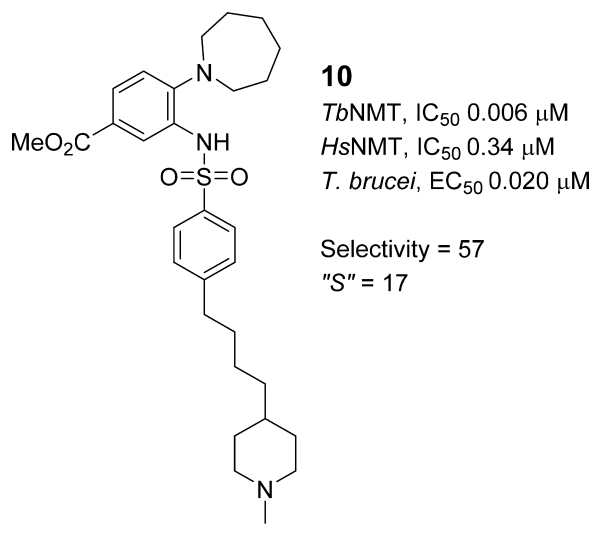

high throughput screening, was at least 10 -fold more selective for TbNMT over HsNMT compared to the pyrazole sulfonamide hit $\mathbf{1}$, making it a potentially attractive start point for optimization. From previous work, a ratio of inhibition of the HsNMT potency compared to activity in a parasite growth assay (selectivity "S" $=H s \mathrm{NMT} \mathrm{IC}_{50} / \mathrm{T}$. brucei $\mathrm{EC}_{50}$ ) was found to give a better indication of selectivity rather than direct comparison of potency at either enzyme. " $S$ " for 4 was also significantly improved (>8.3 compared to 1.0 for $\mathbf{1}$ ). We therefore sought to optimize 4 through exploration of its structure-activity relationships and through hybridization with key elements from the pyrazole sulfonamides with the aim of maximizing selectivity.

Initial work on SAR generated some interesting results, but it proved difficult to rationalize these until we had structural information. Although replacement of the azepane moiety of 4 with a pyrrolidine gave an equipotent compound 5, removal of the azepane group entirely resulted in loss of activity (7). Unexpectedly, piperidine analogue 9 was also inactive. Modifications to substituents on the phenylsulfonamide ring were tolerated (cf. 8). However, carboxylic acid 6 proved inactive (Scheme 2). This was particularly important because the methyl ester undergoes rapid hydrolysis in plasma, which would result in a complete loss of activity. The development of
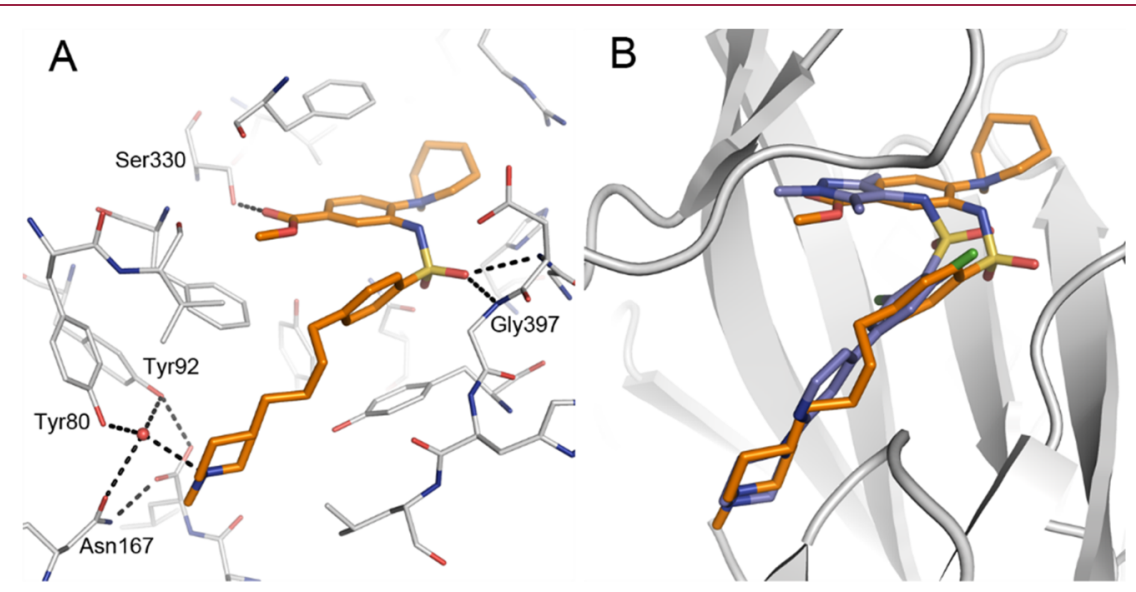

Figure 3. Crystal structure of $L m N M T: M C o A: 10$ showing water-mediated interactions in the C-terminal region. (A) Conformation of 10 (C atoms gold) bound to LmNMT; H-bonds are shown as dashed black lines. (B) Binding mode comparison of 10 with the pyrazole sulfonamide ligand DDD85646 (1; C atoms purple). 
Scheme 4. Design of Isosteres of the Methyl Ester

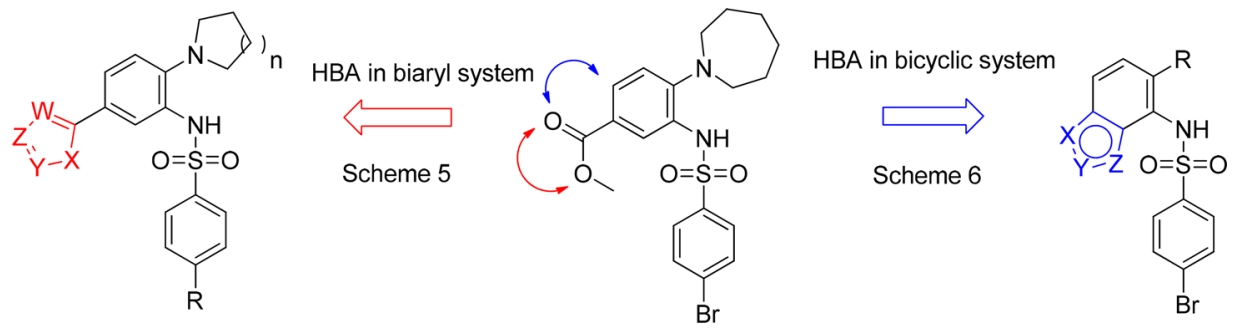

Scheme 5. Biaryl Hydrogen Bond Acceptors

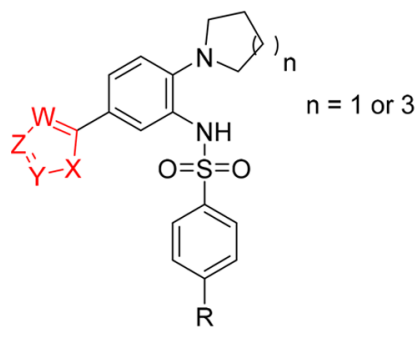<smiles>O=S(=O)(Nc1cc(-c2cccnc2)ccc1N1CCCC1)c1ccc(Br)cc1</smiles>

11

TbNMT $39 \mu \mathrm{M}$

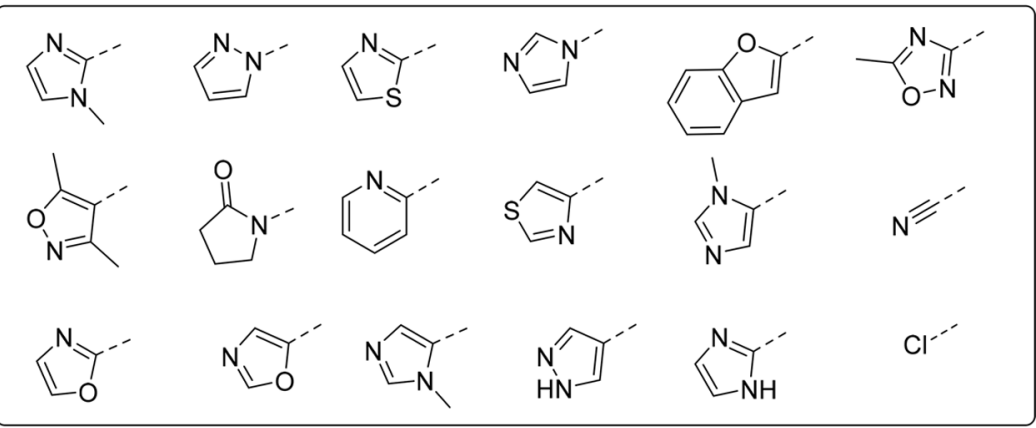

All $>50 \mu \mathrm{M}$ TbNMT

efficacious compounds therefore required the identification of stable ester bioisosteres capable of maintaining activity against NMT in vivo.

Use of Structural Information to Find the Binding Mode of the Methyl Ester Series. We were unable to obtain TbNMT crystal structures; however a structure was obtained for 4 bound to LmNMT:MCoA (Figure 2A) as a surrogate showing the ligand could bind in the peptide binding groove. The main interactions were hydrogen bonds between the ester carbonyl and Ser330 and between a sulfonamide oxygen and Asp396 together with a stacking interaction between the lower phenyl ring and Tyr217. Figure 2B shows the overlay of 4 with pyrazole hit 1 showing that both molecules adopted twisted conformations due to their common sulfonamide motif and formed a similar key hydrogen-bonding interaction with Ser330.

A significant difference was observed, however, in the conformation of the protein when 4 was bound (Figure 2C): there was a conformational change in residues 231-236, part of the DE loop, to alleviate a steric clash between the azepane ring and the side chain of Phe232. This loop is highly flexible as judged by crystallographic B-factors, allowing a $5 \AA$ shift in the position of the Phe232 side chain. The flexibility is facilitated by the Gly234 residue, which is not present in the $H s \mathrm{NMT}$ protein. Hence, this could explain the high selectivity observed for this ligand with the LmNMT (and TbNMT) protein able to change conformation, whereas the HsNMT protein, being less flexible, suffers a steric clash preventing binding of the ligand. Furthermore, the azepane ring was observed to adopt a folded conformation not favorable for a piperidine ring, which might explain the lack of activity of the piperidine analogue (9). The pyrrolidine ring of 18 (a more decorated version of compound 5) can also adopt a similar folded conformation to the azepane of compound $\mathbf{4}$ in agreement with our selectivity hypothesis.

Use of Existing Knowledge of NMT Inhibitors to Increase Potency in the Methyl Ester Series. From our previous work, ${ }^{5,6}$ appending a basic moiety to DDD64558 (1) to reach the C-terminal carboxylic acid gave an $\sim 1000$-fold increase in potency (cf. compounds 2 and 3). ${ }^{5,6}$ Using the crystallographic information, an amine-containing substituent was appended to the arylsulfonamide core of $\mathbf{4}$ to give $\mathbf{1 0}$ (Scheme 3) to place a basic nitrogen adjacent to the $\mathrm{C}$ terminal carboxylic acid (Leu421). This substitution gave a marked increase in potency versus TbNMT and also maintained selectivity over $H_{s} \mathrm{NMT}$. A crystal structure of $\mathbf{1 0}$ bound to $L m \mathrm{NMT}$ :MCoA confirmed that the ligand retained the interactions of $\mathbf{4}$ with the protein, including the azepanegenerated conformational shift. Additional water-mediated interactions with the $\mathrm{C}$-terminal carboxylic acid of the protein accounted for the 150-fold gain in potency (Figure 3). Overlay with the crystal structure of $\mathbf{2}$ showed that the two ligands 
Scheme 6. Activities of Fused Bicyclic Hydrogen Bond Acceptors against TbNMT

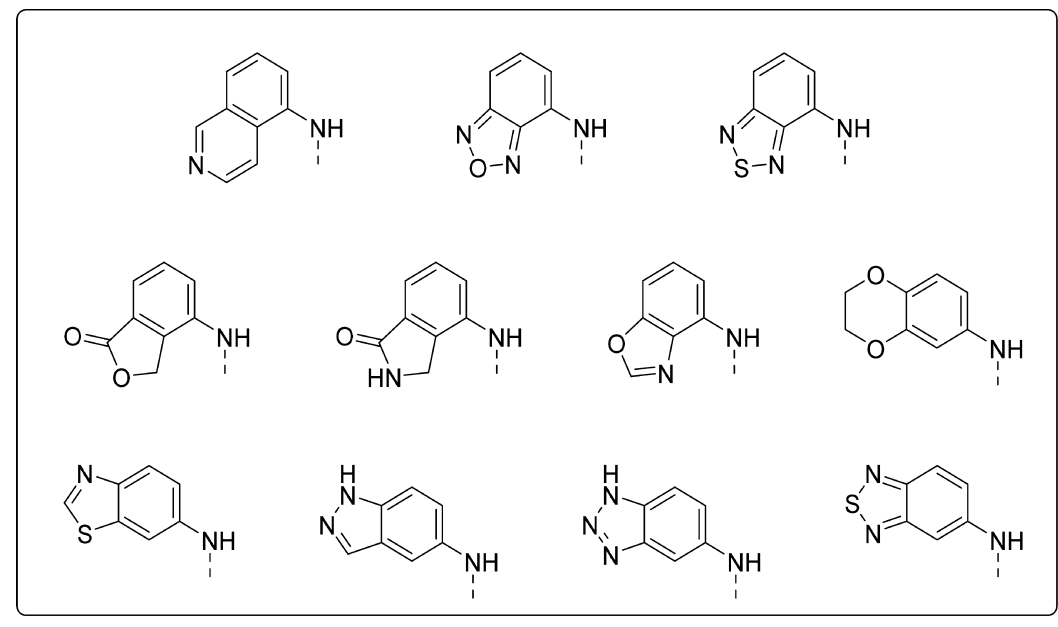

All $>100 \mu \mathrm{M}$ TbNMT

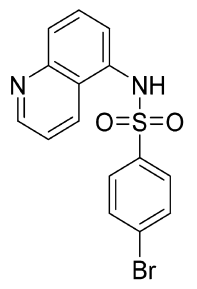

12

$90 \mu \mathrm{M}$

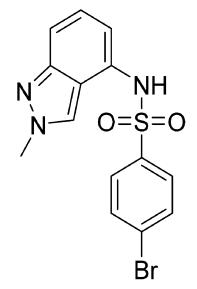

13

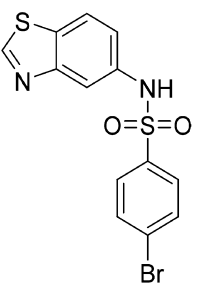

14

$24 \mu \mathrm{M}$ adopted similar conformations with an amine group occupying a very similar position relative to the $\mathrm{C}$-terminus.

Compound 10 was also highly potent against the T. brucei parasite. However, the ester was rapidly hydrolyzed to the inactive acid (cf. 6) in mouse plasma $\left(t_{1 / 2}<15\right.$ min; method in Supporting Information). Two approaches were therefore adopted to find an alternative stable framework, which is isosteric with the ester, to retain the hydrogen bond donor functionality important for binding to Ser330 (Scheme 4).

Biaryl Isostere Strategy to Increase Metabolic Stability. The first approach was to replace the ester with a pendent heterocyclic hydrogen bond acceptor to maintain the $\mathrm{H}$-bond acceptor interaction with Ser330 (Scheme 5). A wide range of heterocycles (pyrazoles, imidazoles, thiazoles, oxazoles, etc.) were investigated. However, all compounds proved inactive in our biochemical assay except 3-pyridyl 11, which showed weak activity, 50-fold lower than that of the methyl ester analogue (cf. 8, Scheme 2).

Bicyclic Isosteres to Improve Metabolic Stability. A second approach was to explore the incorporation of a hydrogen bond acceptor into a fused bicyclic system (Scheme 6 ). It was noted that removal of the azepane or pyrrolidine groups from the methyl ester series $(7$, Scheme 2$)$ resulted in loss of activity. However, to aid ease of synthesis, compounds without an azepane or pyrrolidine substituent were originally prepared. Of these, quinoline 12, indazole 13, and benzothiazole 14 showed weak activity against TbNMT. The quinoline and indazole hits were selected for further studies.

Reinstatement of the azepane group into the quinoline scaffold (22, Table 1) resulted in a compound with similar potency and selectivity to hit compound 4 . Similarly, addition of a pyrrolidine group improved the potency of both quinoline and indazole systems (Scheme 7). The lactone analogue of the methyl ester (15) was inactive.

Quinoline Series. Appending an amine tail to $\mathbf{1 6}$ to reach the C-terminal carboxylic acid of NMT gave 18, resulting in the expected gain in potency while maintaining the selectivity observed with the methyl ester series. A crystal structure of $\mathbf{1 8}$ bound to LmNMT:MCoA (Figure 4) showed that the binding mode of the ester series was retained with the quinoline nitrogen of $\mathbf{1 8}$ forming a similar hydrogen bonding interaction to Ser330 as the ester carbonyl of $\mathbf{4}$. The pyrrolidine ring of $\mathbf{1 8}$ occupies similar space to the azepane of 4 , possibly explaining the retention of high selectivity.

Head Group Optimization. Compounds with an amine in the quinoline 6-position such as $\mathbf{1 6}$ were found to be chemically unstable with mass spectrometry suggesting that oxidation of the pyrrolidine ring under air was occurring. Hence, an array of 6-alkyl-substituted quinolines was prepared (Scheme 8, Table 1). Synthesis was achieved by Negishi coupling with bromide 19 to install the 6-alkyl group (20) followed by nitro reduction and coupling with 4-bromophenylsulfonyl chloride to form sulfonamide $\mathbf{2 1}$.

Removal of an electron-donating nitrogen by replacement of the 6-pyrrolidine with a 6-cyclopentyl group (24) resulted in a chemically stable compound with similar potency. However, substitution with a cyclohexyl or phenyl ring $(25,26)$ resulted in loss of activity. This is consistent with the observed loss of activity for a piperidine substituent in the methyl ester series (9, Scheme 2). Benzyl and 3-pentyl groups were tolerated (29, 30 ), but the best potency was obtained with isobutyl and cyclohexylmethyl groups $(\mathbf{2 7}, \mathbf{2 8})$. Of these, the isobutyl substituent (27) showed good potency and selectivity with the minimum of addition of molecular weight and lipophilicity, i.e., equal ligand efficiency $(\mathrm{LE})^{24}$ but improved ligand-lipophilicity 


\section{Table 1. Quinazoline Head Group Optimization}

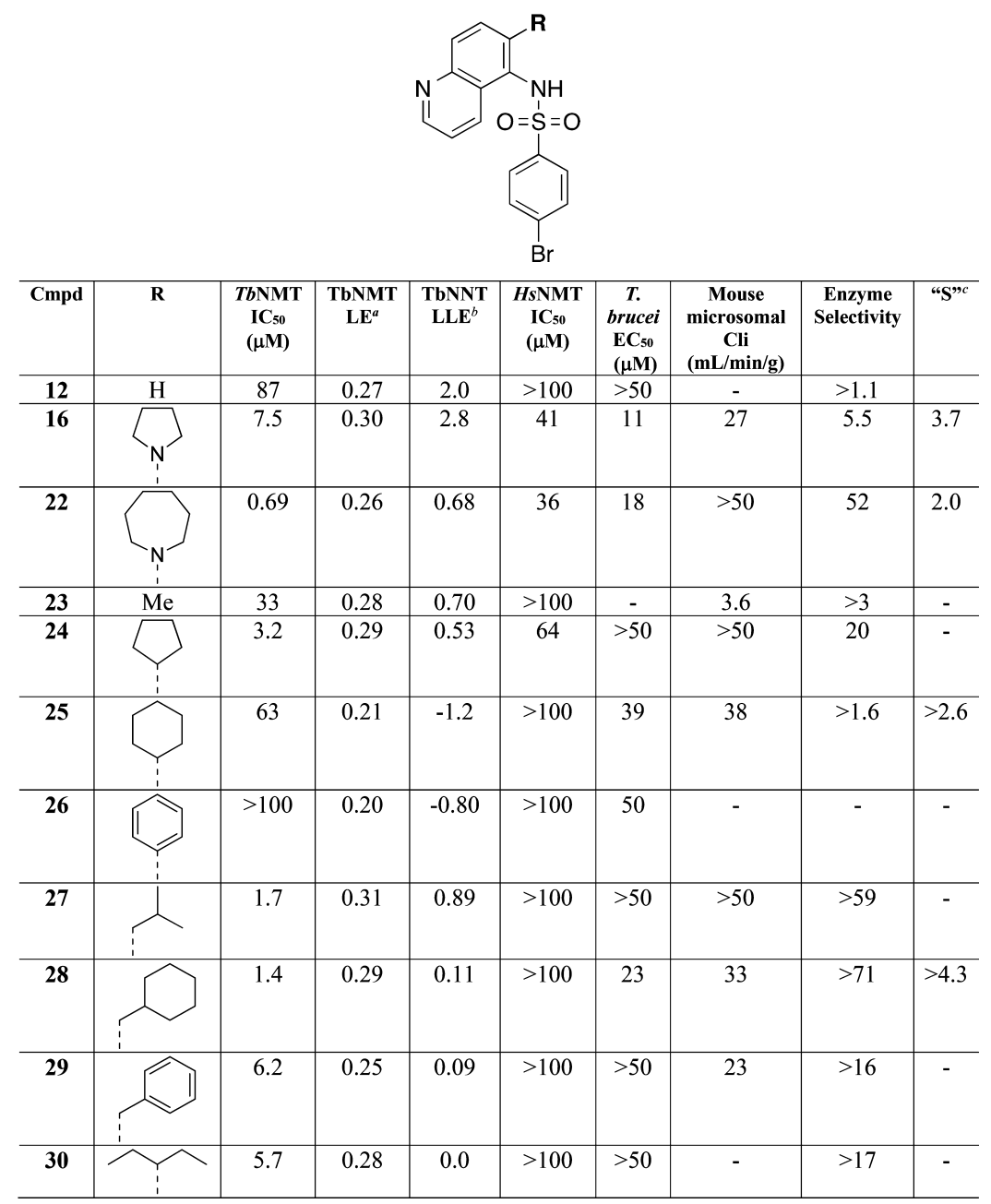

${ }^{a} \mathrm{LE}=$ ligand efficiency $(\Delta G /$ number of non-hydrogen atoms $) .{ }^{b} \mathrm{LLE}=$ ligand-lipophilicity efficiency $\left(\mathrm{pIC}_{50}-\operatorname{clogP}\right) .{ }^{25} c$ “s” $=H s \mathrm{NMT} \mathrm{IC} \mathrm{C}_{50} / \mathrm{T}$. brucei $\mathrm{EC}_{50}$.

Scheme 7. Fused Bicycles with an Added Amino Group<smiles>O=C1OCc2c1ccc(N1CCCC1)c2NS(=O)(=O)c1ccc(Br)cc1</smiles>

15

TbNMT $>100 \mu \mathrm{M}$<smiles>O=S(=O)(Nc1c(N2CCCC2)ccc2ncccc12)c1ccc(Br)cc1</smiles>

16

TbNMT $7 \mu \mathrm{M}$<smiles>Cn1cc2c(NS(=O)(=O)c3ccc(Br)cc3)c(N3CCCC3)ccc2n1</smiles>

17

TbNMT $27 \mu \mathrm{M}$<smiles>O=S(=O)(Nc1c(N2CCCCCC2)ccc2ncccc12)c1ccc(Br)cc1</smiles>

22

TbNMT $0.69 \mu \mathrm{M}$ efficiency (LLE), ${ }^{25}$ and was thus selected for further optimization.

Appending an alkyl chain-linked piperidine "tail" (31 and 32, see Table 2) to the 6-isobutylquinoline system gave the expected improvement in potency in analogous fashion to that observed in the pyrazole and methyl ester series (cf. compounds 3 and 10). The crystal structure of 32 bound to LmNMT:MCoA showed that the overall binding mode of the series was retained with the 6-isobutyl group sufficient to induce the conformational change in residues 231-236 that is proposed to confer selectivity over HsNMT (Figure 5).
Strategy to Increase Selectivity in the Quinoline Series by Tail Group Optimization. It was known from our previous work in the pyrazole sulfonamide series that selectivity could be improved by optimization of the aminecontaining "tail group" moiety. ${ }^{6}$ Hence, combining the selectivity conferred by the quinoline isobutyl substituent with that conferred by different terminal amines was attempted. An array of alternative pendant amines was then prepared in the search for more selective compounds (Table 2 ). The amine moieties were appended by first hydroboration of an appropriate alkene precursor with $9-\mathrm{BBN}$ followed by 

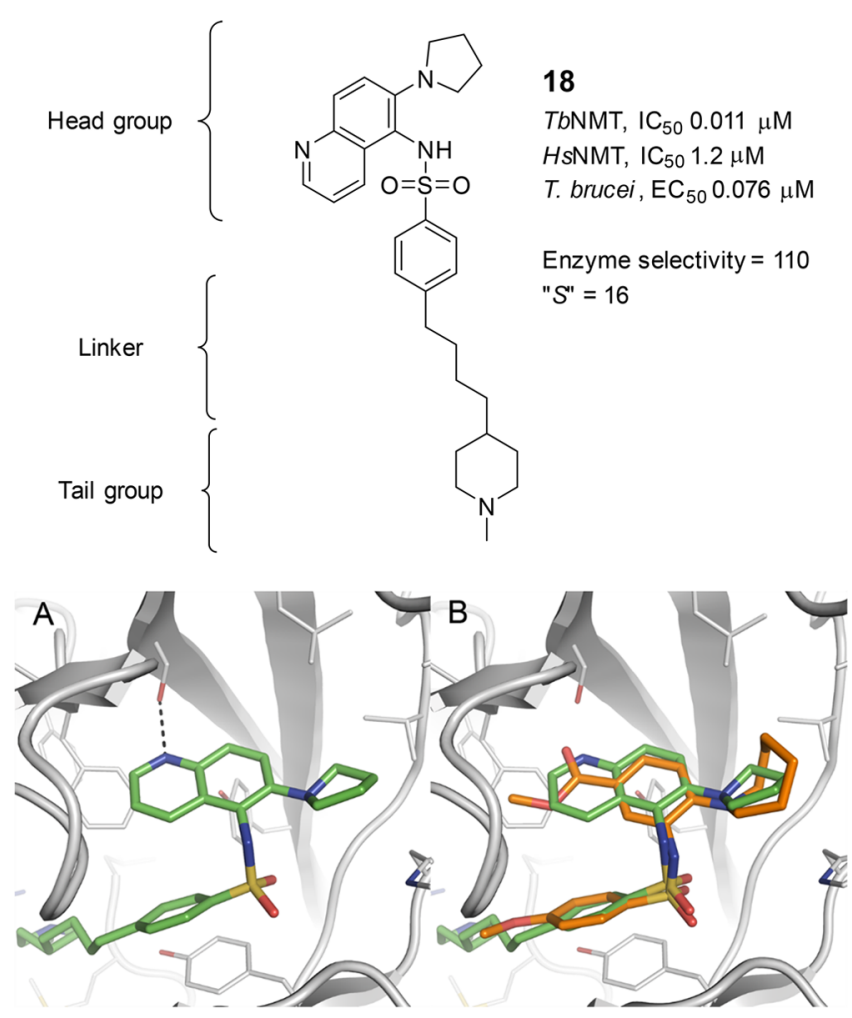

Figure 4. Crystal structure of 18 bound to $L m \mathrm{NMT}: M C o A$. (A) Binding mode of 18 ( $\mathrm{C}$ atoms green) highlighting the H-bond between the quinolone nitrogen and the side chain of Ser330. (B) Comparison of the binding mode of 18 with 4 ( $\mathrm{C}$ atoms gold). The quinolone $\mathrm{N}$ atom mimics the ester carbonyl of 4 .

\section{Scheme 8. Compounds $18-21^{a}$}

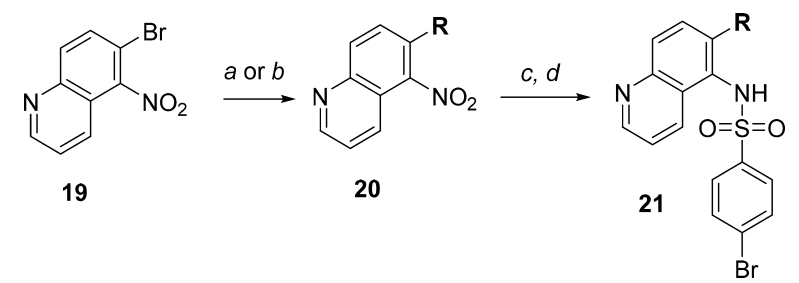

${ }^{a}$ (a) (R = alkyl, phenyl) RZnBr, Pd(dppf) $\mathrm{Cl}_{2}, \mathrm{CuI}$, DMF, THF, 80 ${ }^{\circ} \mathrm{C}$; (b) $(\mathrm{R}=$ amino) azepane or pyrrolidine, toluene, microwave 110 ${ }^{\circ} \mathrm{C}$; (c) $\mathrm{H}_{2}, \mathrm{Pd} / \mathrm{C}$, EtOAc or $\mathrm{Zn}, \mathrm{NH}_{4} \mathrm{Cl}$, THF, $\mathrm{MeOH}, \mathrm{H}_{2} \mathrm{O}$; (d) 4$\mathrm{BrPhSO}_{2} \mathrm{Cl}$, pyridine, $\mathrm{CH}_{2} \mathrm{Cl}_{2}$ (see Table 1 for the different " $\mathrm{R}$ " groups: compounds $\mathbf{2 2 - 3 0}$ ).

Suzuki coupling of the crude borane with bromide 27 (Scheme 9). ${ }^{26,27}$ In some cases, a t-Boc-protected amine precursor was used. These $\mathrm{t}$-Boc-protected products were converted into secondary amines by cleavage of the t-Boc group with TFA or into $N$-methyl amines by cleavage of the t-Boc group followed by reductive amination with paraformaldehyde or directly by reduction of the $\mathrm{t}$-Boc group with lithium aluminum hydride.

Over 100-fold selectivities for TbNMT over $H s$ NMT were achieved for a range of amine substituents. Piperidine $(32,43)$, piperazine $(39,40)$, homopiperazine (37), fused-piperazine $(34,35)$, and ether-linked morpholino groups $(44,45)$ all gave highly selective compounds. Generally, piperazines were more selective than piperidines (but less potent, cf. 31 vs 38,33 vs 39 ), as noted previously. ${ }^{5,6}$ Secondary amines and their $N$ methyl-capped analogues tended to show similar activities (cf. 32 vs 33, 44 vs 45 ). The length of the linker chain could affect selectivity " $S$ " with the longer butyl linker giving better selectivity (cf. 31 vs 32,36 vs 37 ). The stereochemistry of the ligand could also affect selectivity (cf. 41 vs 42 ). Adding bulk to the ligand could also improve selectivity (cf. 39 vs 40 ).

However, by far the most selective compound was the pseudotropine-derived compound 41, which was nearly 4000fold selective (enzyme selectivity 3900 ; "S" = 325). Interestingly, the analogous tropine-derived compound (42) was much less selective (albeit more potent). The pseudotropine group was known to confer modest selectivity in the pyrazole series (cf. DDD101140; Figure 6). ${ }^{6}$ Therefore, we had established, at least in this case, that a synergistic combination of selective "head" (the isobutylquinoline) and "tail" (the pseudotropine) groups resulted in a compound with extremely high selectivity. The origin of the contribution to selectivity, which the pseudotropine group makes, is unknown. A crystal structure of this ligand bound to $L m N M T$ could not be obtained. The region of the active site around the $\mathrm{C}$ terminus is highly conserved between species with no obvious differences that could explain differences in selectivity. It is possible that the particular size and shape of the pseudotropine ligand can be better accommodated in the T. brucei enzyme due to differences in protein flexibility or the stability of the water molecules that form the hydrogen bonding network.

In general, these compounds had lower potency against the T. brucei parasite than the pyrazole series (e.g., compound 3). This is in keeping with lower potency against the TbNMT enzyme $(2-16 \mathrm{nM}$ for the quinoline series against typically $<2$ $\mathrm{nM}$ for the pyrazole series).

Indazole Series Headgroup Optimization. A 5pyrrolidinylindazole, 17 (Scheme 7), had also shown some activity against $\mathrm{TbNMT}$, and a series of indazoles were also evaluated as a quinoline surrogate. A limited array of 5alkylindazoles was prepared based around the most successful compounds in the quinoline series (Table 3) using a similar chemical route (Scheme 10). An isobutyl group (51) again resulted in good potency and selectivity, as did a methylcyclohexyl group (52). In this series, these two compounds showed at least 10 -fold better potency than those compounds with a cyclic group appended directly to the indazole.

Tail Group Optimization to Increase Selectivity in the Indazole Series. The tail group amine was then optimized in analogous fashion to the quinoline series (Table 4). Synthesis was performed using the same hydroboration-Suzuki coupling protocol utilized for the quinoline series (Scheme 11). Groups that gave good selectivity in the quinoline series (Table 2) also performed well in the indazole series, often with improved selectivity over the analogous quinoline. Six compounds were found to have greater than 500-fold selectivity for TbNMT over $H s$ NMT $(55,57,58,60,61$, and 62) with the pseudotropine-derived compound $\mathbf{6 0}$ again showing the greatest selectivity ("S" = 318). A crystal structure of the 5isobutyl indazole ligand $\mathbf{5 4}$ bound to LmNMT:MCoA showed the binding mode to be comparable to the 6-isobutyl quinoline with the indazole $\mathrm{N} 1$ lone pair forming the key H-bond to Ser330 (Figure 7). The binding mode of the remainder of the molecule is highly conserved with all key interactions described previously retained. The indazole series showed better potency against $T$. brucei than the quinoline series in keeping with its higher potency against the TbNMT enzyme.

DMPK and in Vivo Efficacy. DMPK data for key compounds are shown in Table 5. Compounds demonstrated a range of mouse microsomal intrinsic clearance with examples 


\section{Table 2. Tail Group Optimization ${ }^{a}$}

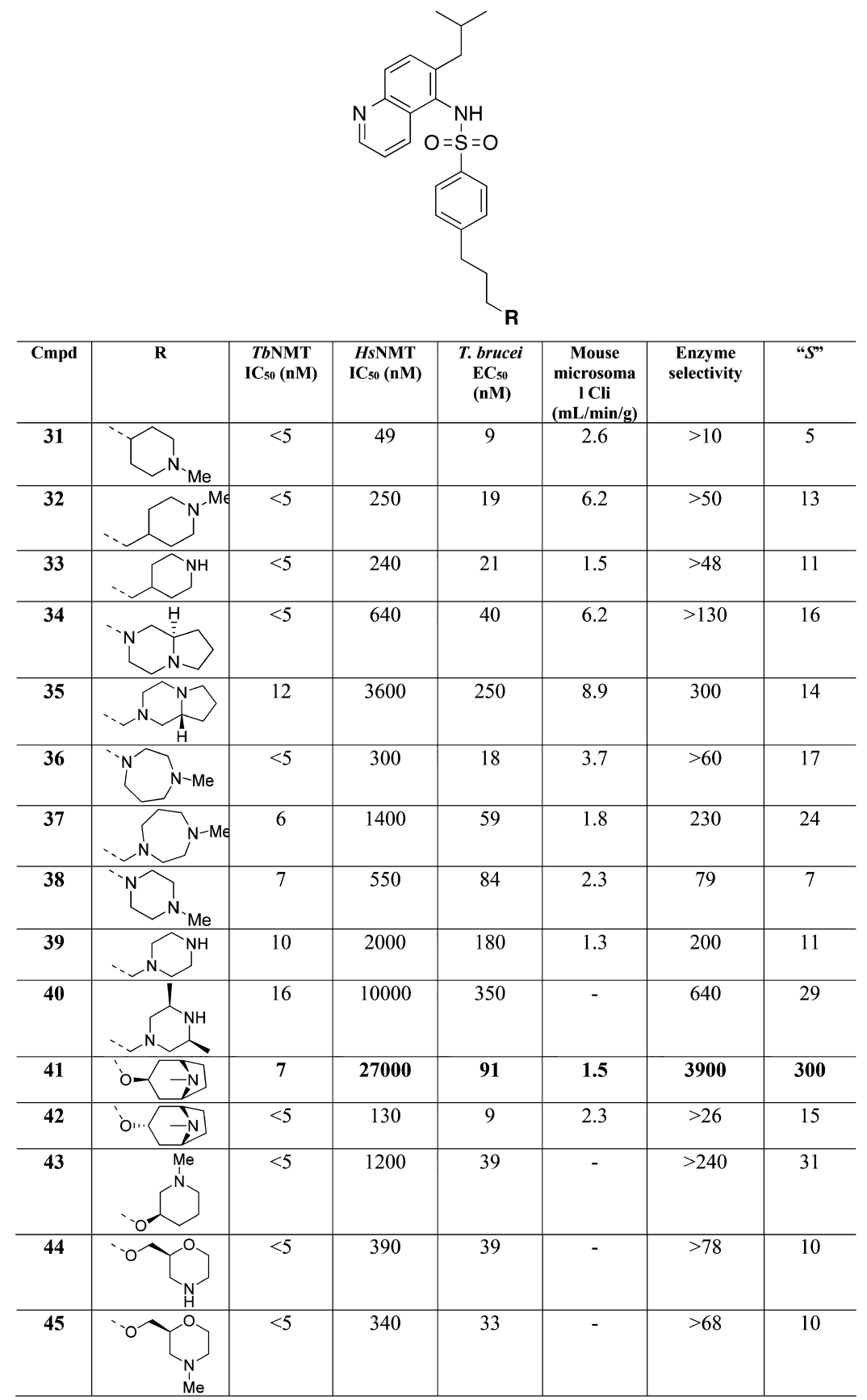

${ }^{a}$ See Supporting Information for full table. "S" $=H s \mathrm{NMT} \mathrm{IC}_{50} / T$. brucei $\mathrm{EC}_{50}$

from both indazole and quinoline series having acceptable metabolic stability (i.e., Cli $<5 \mathrm{~mL} \mathrm{~min}^{-1} \mathrm{~g}^{-1}$ ). Metabolite identification studies on one of the more metabolically unstable quinoline series compounds, 32, following incubation with mouse liver microsomes, suggested that oxidation of the central phenyl ring, or of the alkyl chain linker, predominated rather than $\mathrm{N}$-demethylation or isobutyl group metabolism. Both series also demonstrated moderate to low plasma protein binding. One major concern was hERG inhibition with both series demonstrating low micromolar inhibition, potentially driven by the basic, terminal amine group. Standard techniques to reduce hERG inhibition are to lower lipophilicity and basicity. ${ }^{28,29}$ To this end, a series of compounds bearing a morpholine group were prepared, as this gave compounds with the desired lower $\log \mathrm{D}$ and $\mathrm{p} K_{\mathrm{a}}$ (See Figure 8). No significant improvement in hERG activity was observed, and a substantial penalty was paid in unacceptably high metabolic instability.

Because of its markedly superior $\mathrm{EC}_{50}$ against the T. brucei parasite and acceptable metabolic stability (Cli), compound 54 was selected for progression toward a stage I mouse efficacy model of HAT. When dosed orally at $50 \mathrm{mg} / \mathrm{kg}, 54$ demonstrated good exposure $\left(\mathrm{AUC}_{0-8}=2,900,000 \mathrm{ng}-\mathrm{min} /\right.$ $\mathrm{mL} ; C_{\max }=11,000 \mathrm{ng} / \mathrm{mL} ; T_{\max }=1 \mathrm{~h}$ ) and in keeping with its high " $S$ " value (47), 54 was well-tolerated (maximum tolerated dose $>300 \mathrm{mg} / \mathrm{kg}$ when dosed twice a day orally for 3 days). In the stage 1 HAT mouse model, with female NMRI mice infected with T. brucei s427, compound 54 was fully curative at $10 \mathrm{mg} / \mathrm{kg}$ when dosed twice a day orally for 4 days, starting 


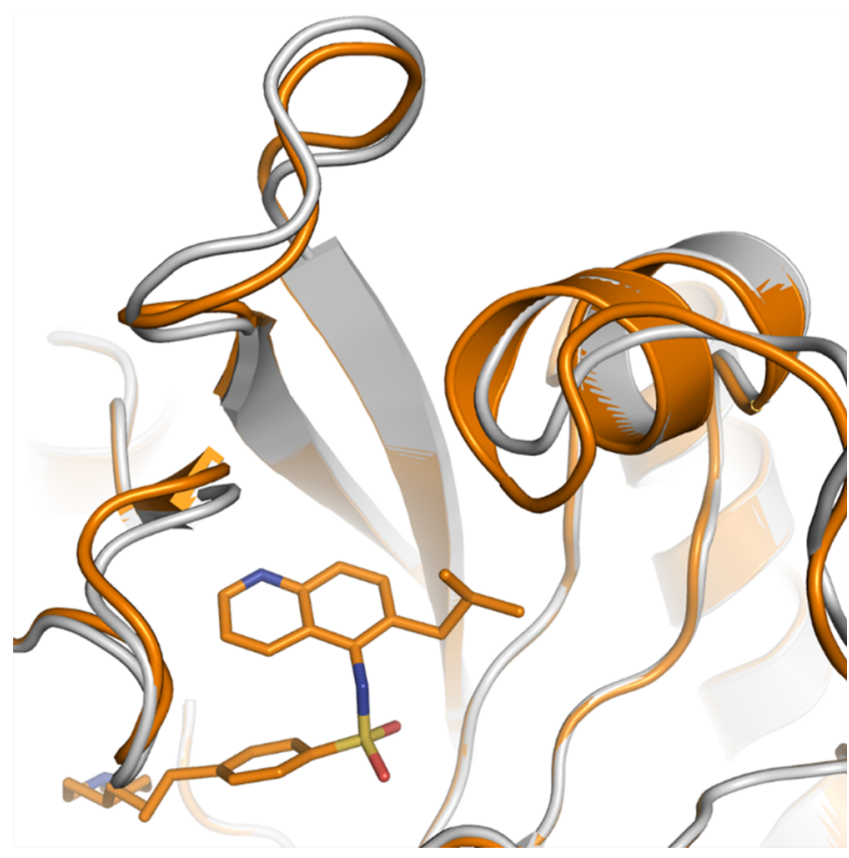

Figure 5. Crystal structure of the 6-isobutyl derivative 32 bound to LmNMT:MCoA. Structure of 32 (C atoms gold) bound to $L m M N T$ (gold ribbon). The main chain of $L m N M T$ bound to the pyrolidine derivative $\mathbf{1 8}$ is overlaid (gray ribbon).

\section{Scheme 9. Compound $27^{a}$}

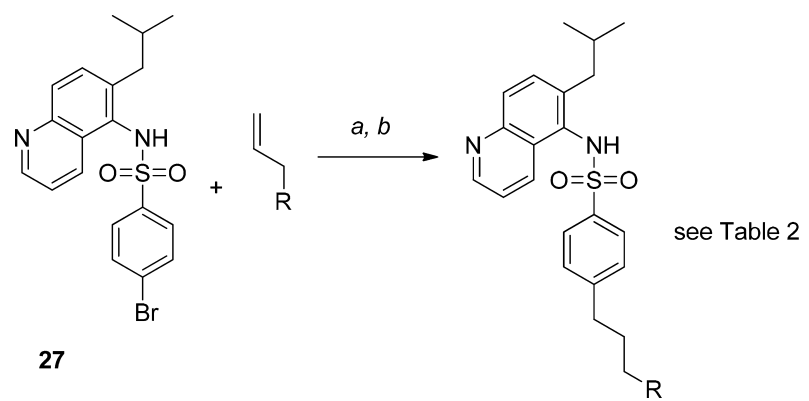

${ }^{a}$ (a) 9-BBN, THF, reflux; (b) $\mathrm{Pd}(\mathrm{dppf}) \mathrm{Cl}_{2}, \mathrm{~K}_{3} \mathrm{PO}_{4}, \mathrm{DMF}, \mathrm{H}_{2} \mathrm{O}$ (see Table 2 for the different " $\mathrm{R}$ " groups: compounds 31-45; in some cases, an additional synthetic step was required, see the Supporting Information for details).

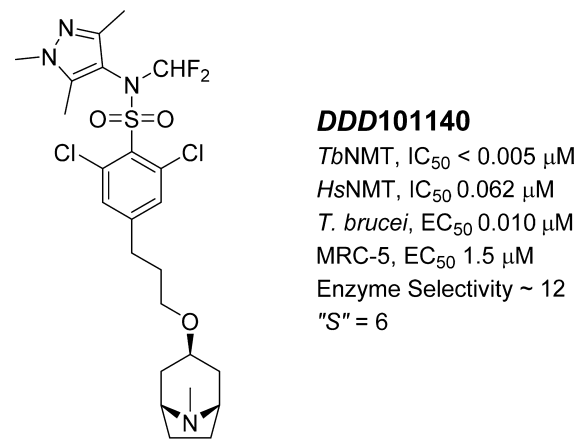

Figure 6. Modest selectivity afforded by a pseudotropine substituent (published previously: compound $\mathbf{7 1}$ in Supporting Information ${ }^{6}$ ).

day 3 postinfection. All animals relapsed at dose levels of $0.3,1$, or $3 \mathrm{mg} / \mathrm{kg}$ orally twice daily for 4 days. Assuming linearity of exposure, the free $C_{\max }$ at the minimal efficacious dose $(10 \mathrm{mg}$ / $\mathrm{kg}$ ) would only give a cardiovascular window of $\sim 10$-fold, highlighting a significant issue for progression for this series unless hERG liability could be reduced while maintaining high potency.

The ability to cross the blood-brain barrier is essential for treatment of stage $2 \mathrm{HAT}$, when the parasites are present in the central nervous system. Compounds in the quinoline series were brain penetrant but unfortunately lacked the right balance of potency and metabolic stability for progression. Furthermore, the hERG inhibition was marginally higher within this series. In contrast, the indazole series was very poorly brain penetrant, and for 54, the most profiled exemplar from the series, the observed very poor brain penetration was demonstrated to be due to the fact it was a strong Pglycoprotein substrate. Following coadministration in rat with the Pgp inhibitor, GF120918, the brain:blood ratio for $\mathbf{5 4}$ increased to 2.2 (0.09 without GF120918 coadministration).

Validation of NMT as a Drug Target for Stage 2 HAT. In previous studies, we had validated NMT as a drug target in stage $1 \mathrm{HAT}^{4-6}$ However, these molecules were not brain penetrant or did not offer sufficient tolerability in rodents to be able to deliver a dosing regimen to conclusively validate NMT as a viable drug target in stage $2 \mathrm{HAT}$. Owing to its high potency against the T. brucei parasite, good oral pharmacokinetics and excellent tolerability, $\mathbf{5 4}$ appeared to be a good tool molecule to validate NMT for stage 2 HAT. For the purposes of the stage 2 HAT model, the poor CNS penetration of 54 could be overcome by using CF-1 mdrla deficient mice. ${ }^{30}$ Using this model, a completely curative dosing regimen was obtained for $\mathbf{5 4}$ (Figure 9) at $50 \mathrm{mg} / \mathrm{kg}$ orally twice daily for 5 days, validating NMT as a suitable drug target for stage 2 HAT. Using female NMRI mice, not mdrla deficient, compound 54 relapsed at all dose levels $(50,100$, and $200 \mathrm{mg} / \mathrm{kg}$ orally twice daily for 5 days) in the stage 2 model.

We have previously shown that poor CNS penetration could be overcome by application of a metabolically stable difluoromethyl "cap" to the sulfonamide. ${ }^{6}$ Pleasingly, when this modification was made to indazole 54 (i.e., 66, see Scheme 12) the brain:blood ratio was significantly improved (1.9 vs < 0.1 , whereas other properties were largely left unaffected, including trypanocidal activity, metabolic stability (mouse Cli $=2.3 \mathrm{~mL} / \mathrm{min} / \mathrm{g}$ ), selectivity " $S$ " and also unfortunately hERG $\left(\mathrm{IC}_{50}=6 \mu \mathrm{M}\right)$. Consequently, because of the likely unacceptable cardiovascular safety window (this was only $\sim 3$-fold at $50 \mathrm{mg} / \mathrm{kg}$, delivering stage 2 efficacy for 54), 66 was not progressed further.

\section{CONCLUSIONS}

We show here that for the first time it is possible to obtain inhibitors of TbNMT that are highly potent, selective, and CNS penetrant (i.e., 41 and 66). The substantial gains in selectivity achieved relative to earlier series has resulted from the additive effect of combining selectivity-enhancing pendent amines from a previous series with new highly selective head groups, which translates into improved tolerability in vivo.

High-throughput screening identified 4, an inhibitor of TbNMT, with selectivity over HsNMT. A chemistry campaign based around crystal structures of the ligand bound to $L m N M T$ led to the discovery of two novel alternative scaffolds: one based on a quinoline and one based on an indazole. Both scaffolds showed good potency and selectivity for the parasite enzyme. From crystallographic studies of our previous pyrazole series, we were able to hybridize these 
Table 3. Indazole Head Group Optimization

\begin{tabular}{|c|c|c|c|c|c|c|c|}
\hline Cpmd & $\mathbf{R}$ & $\begin{array}{c}\text { TbNMT } \\
\text { IC } 50(\mu \mathrm{M})\end{array}$ & $\begin{array}{c}H s N M T \\
I_{50}(\mu \mathrm{M})\end{array}$ & $\begin{array}{c}\text { T. brucei } \\
\text { EC }_{50} \\
(\mu \mathrm{M})\end{array}$ & $\begin{array}{c}\text { Mouse } \\
\text { microsomal } \\
\text { Cli } \\
(\mathrm{mL} / \mathrm{min} / \mathrm{g})\end{array}$ & $\begin{array}{c}\text { Enzyme } \\
\text { Selectivity }\end{array}$ & "S" \\
\hline 17 & & 27 & $>100$ & 24 & 33 & $>3.7$ & $>4.1$ \\
\hline 13 & $\mathrm{H}$ & 27 & $>100$ & $>50$ & 6.3 & $>3.7$ & - \\
\hline 49 & & 26 & $>100$ & $>50$ & - & $>3.8$ & - \\
\hline 50 & & 17 & $>100$ & 32 & - & $>5.9$ & $>3.1$ \\
\hline 51 & & 1.1 & $>100$ & $>50$ & - & $>91$ & - \\
\hline 52 & & 1.7 & $>100$ & $>50$ & - & $>59$ & - \\
\hline & & & & & & & \\
\hline
\end{tabular}

Scheme 10. Compounds $46-48^{a}$

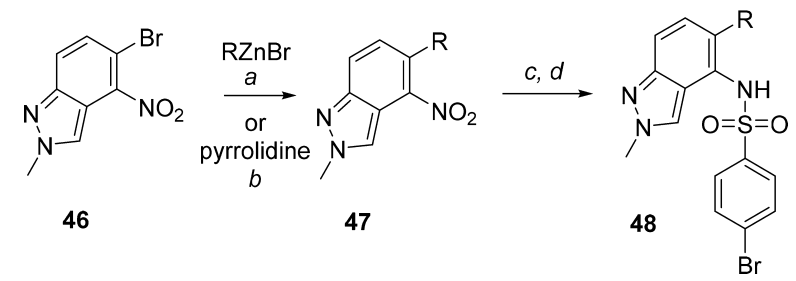

${ }^{a}$ (a) $\mathrm{RZnBr}, \mathrm{Pd}(\mathrm{dppf}) \mathrm{Cl}_{2}$, CuI, DMF, THF, $80{ }^{\circ} \mathrm{C}$ (for compounds 49-52); (b) pyrrolidine, toluene, microwave $110^{\circ} \mathrm{C}$ (for compound 17); (c) $\mathrm{H}_{2}, \mathrm{Pd} / \mathrm{C}$; (d) 4- $\mathrm{BrPhSO}_{2} \mathrm{Cl}$, pyridine, $\mathrm{CH}_{2} \mathrm{Cl}_{2}$ (see Table 3 for the different " $\mathrm{R}$ " groups: compounds 49-52).

scaffolds with our previous pyrazole series leading to compounds with potent activity against TbNMT and greater than 1000-fold selectivity for TbNMT vs HsNMT and with "S" values ranging from 10 - up to 300 -fold. Although some of these compounds had antitrypanocidal activities with $\mathrm{EC}_{50}<$ $100 \mathrm{nM}$, in general they were less potent than the pyrazole series with which we had previously worked. Some of the quinoline series showed blood-brain barrier penetration, but none had the right balance of potency against the parasite, metabolic stability, and selectivity to progress further. In contrast, one of the indazole compounds, 54, had good potency against the $\mathrm{T}$. brucei parasite $\left(\mathrm{EC}_{50}=5 \mathrm{nM}\right)$, good microsomal stability $(\mathrm{Cli}=2.9 \mathrm{~mL} / \mathrm{min} / \mathrm{g})$, good selectivity (“S” = 47), good oral exposure, and good in vivo tolerability. It was efficacious in a stage 1 mouse model of HAT and could potentially be further developed as a drug to treat stage 1 of the disease, except the cardiovascular toxicity window was too low because of the hERG liability. Although, compound 54 lacked sufficient brain penetration for treating stage 2 HAT as a consequence of strong Pgp interaction, a fully curative oral dose regimen was achieved in the stage 2 GVR35 mouse model of HAT when using CF1 mdrla deficient mice for the infection. This validates NMT as a drug target for stage 2
HAT. It remains to be seen whether this series offers the potential to deliver a lead with all the properties required for further development toward a treatment for both stages of HAT, particularly with regard to a molecule potent against the parasite, having good pharmacokinetics and brain penetration and an acceptable cardiovascular safety window.

\section{EXPERIMENTAL SECTION}

General Experimental Information. Chemicals and solvents were purchased from the Aldrich Chemical Co., Fluka, ABCR, VWR, Acros, Fisher Chemicals, and Alfa Aesar and were used as received unless otherwise stated. Air- and moisture-sensitive reactions were carried out under an inert atmosphere of argon in oven-dried glassware. Analytical thin-layer chromatography (TLC) was performed on precoated TLC plates (layer $0.20 \mathrm{~mm}$ silica gel 60 with fluorescent indicator UV254 from Merck). Developed plates were airdried and analyzed under a UV lamp (UV254/365 nm). Flash column chromatography was performed using prepacked silica gel cartridges (230-400 mesh, 40-63 $\mu \mathrm{m}$, from SiliCycle) using a Teledyne ISCO Combiflash Companion or Combiflash Retrieve. ${ }^{1} \mathrm{H}$ NMR spectra were recorded on a Bruker Avance II 500 spectrometer $\left({ }^{1} \mathrm{H}\right.$ at 500.1 $\mathrm{MHz})$ or a Bruker DPX300 spectrometer $\left({ }^{1} \mathrm{H}\right.$ at $\left.300.1 \mathrm{MHz}\right)$. Chemical shifts $(\delta)$ are expressed in ppm recorded using the residual solvent as the internal reference in all cases. Signal splitting patterns are described as singlet $(\mathrm{s})$, doublet $(\mathrm{d})$, triplet $(\mathrm{t})$, quartet $(\mathrm{q})$, multiplet $(\mathrm{m})$, broad (b), or a combination thereof. Coupling constants $(J)$ are quoted to the nearest $0.1 \mathrm{~Hz}$. LC-MS analyses were performed with either an Agilent HPLC 1100 series connected to a Bruker Daltonics MicrOTOF or an Agilent Technologies 1200 series HPLC connected to an Agilent Technologies 6130 quadrupole LCMS, where both instruments were connected to an Agilent diode array detector. All assay compounds had a measured purity of $\geq 95 \%$ as determined using this analytical LC-MS system (TIC and UV). Highresolution electrospray measurements were performed on a Bruker Daltonics MicrOTOF mass spectrometer. Microwave-assisted chemistry was performed using a Biotage Initiator Microwave Synthesizer. Purity (>97\%) and molecular mass were confirmed by HPLC and high-resolution mass spectrometry.

Prototypical Procedure for the Negishi Coupling between an Aryl Bromide and an Alkylzinc Reagent. 6-Isobutyl-5- 
Table 4. Indazole Tail Group Optimization

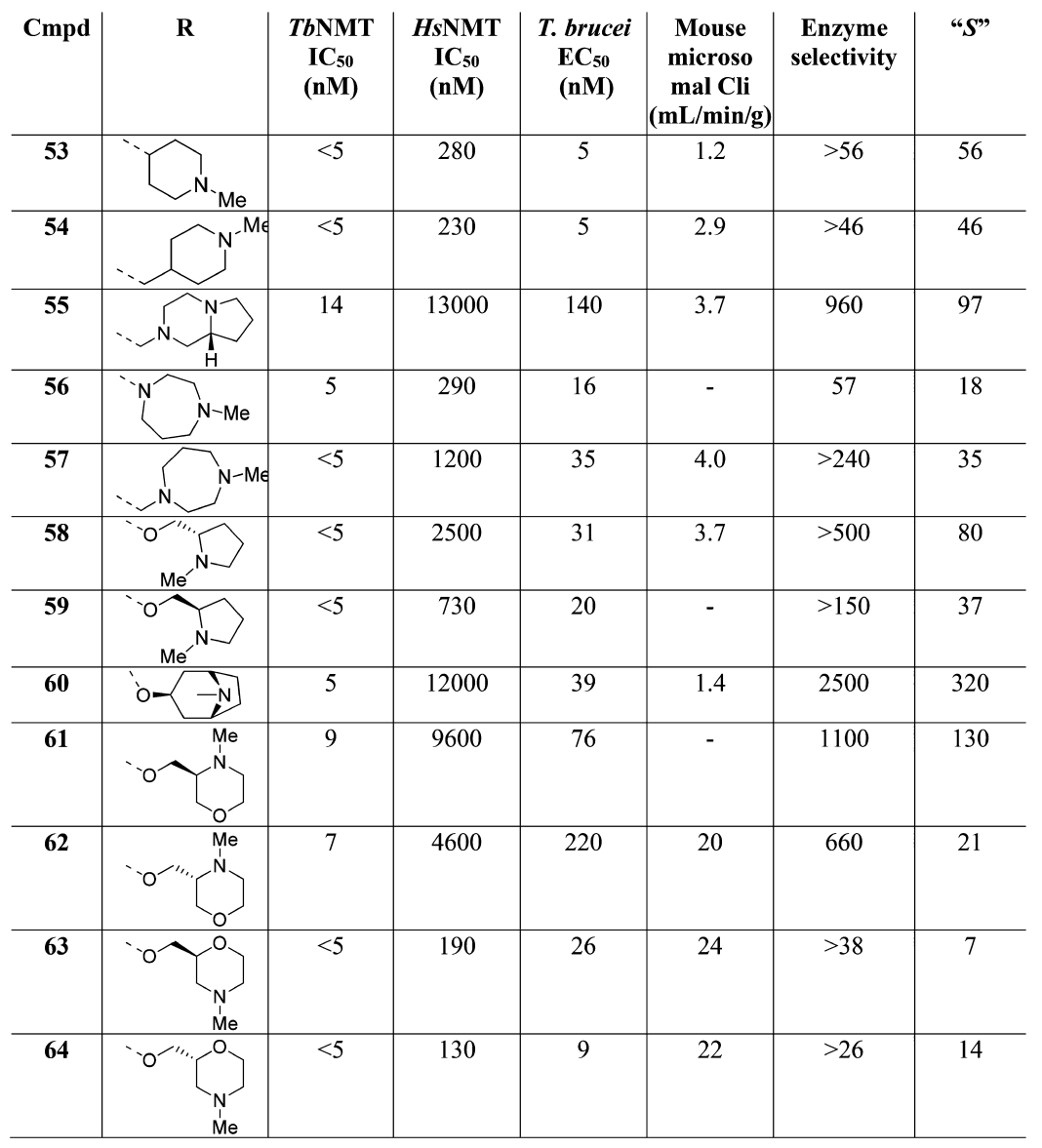

Scheme 11. Compound $51^{a}$<smiles>[R]CC=CC</smiles>

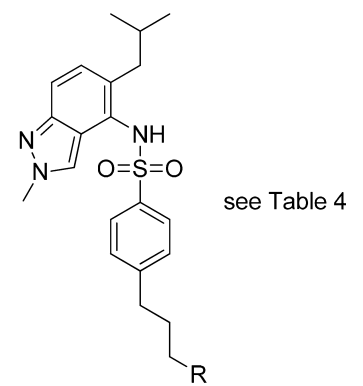

${ }^{a}$ (a) 9-BBN, THF, reflux; (b) $\mathrm{Pd}(\mathrm{dppf}) \mathrm{Cl}_{2}, \mathrm{~K}_{3} \mathrm{PO}_{4}, \mathrm{DMF}, \mathrm{H}_{2} \mathrm{O}$. In some cases, an additional synthetic step was required, see the Supporting Information for details.

nitroquinoline. 6-Bromo-5-nitroquinoline (0.378 g, $1.49 \mathrm{mmol})$, $\mathrm{Pd}(\mathrm{dppf}) \mathrm{Cl}_{2} \cdot \mathrm{CH}_{2} \mathrm{Cl}_{2}(66 \mathrm{mg}, 0.08 \mathrm{mmol}, 5 \mathrm{~mol} \%)$, and copper(I) iodide (48 $\mathrm{mg}, 0.25 \mathrm{mmol}, 17 \mathrm{~mol} \%$ ) were added to a dry $50 \mathrm{~mL}$ flask under argon. The flask was purged three times with a vacuum/ argon cycle, and DMF $(12 \mathrm{~mL})$ was added. The mixture was stirred at room temperature, and the flask was purged a further three times with a vacuum/argon cycle. The mixture was cooled to $0{ }^{\circ} \mathrm{C}$, and a $0.5 \mathrm{M}$ solution of the isobutylzinc bromide in THF $(4.5 \mathrm{~mL}, 2.25 \mathrm{mmol}, 1.5$ equiv) was added dropwise. The mixture was then heated at $80{ }^{\circ} \mathrm{C}$ overnight.

The reaction mixture was then concentrated, treated with EtOAc $(20 \mathrm{~mL})$ and water $(20 \mathrm{~mL})$, and stirred vigorously for $30 \mathrm{~min}$. The mixture was filtered; the phases were separated, and the aqueous phase was extracted with further EtOAc $(2 \times 20 \mathrm{~mL})$. The combined organic extracts were washed with water and brine, dried $\left(\mathrm{Na}_{2} \mathrm{SO}_{4}\right)$, filtered through a plug of $\mathrm{SiO}_{2}$, and concentrated. The products were purified by flash chromatography on silica (0-100\% EtOAc-hexane) to give the title compound as a brown gum $(311 \mathrm{mg}, 1.43 \mathrm{mmol}$, $96 \%)$.

${ }^{1} \mathrm{H}$ NMR $\left(\mathrm{CDCl}_{3}, 500 \mathrm{MHz}\right) \delta 8.99(1 \mathrm{H}, \mathrm{d}, J=4.2 \mathrm{~Hz}), 8.20(1 \mathrm{H}$, $\mathrm{d}, J=8.8 \mathrm{~Hz}), 8.07(1 \mathrm{H}, \mathrm{ddd}, J=8.6,1.4,0.7 \mathrm{~Hz}), 7.64(1 \mathrm{H}, \mathrm{d}, J=$ $8.8 \mathrm{~Hz}), 7.56(1 \mathrm{H}, \mathrm{dd}, J=8.6,4.2 \mathrm{~Hz}), 2.71(2 \mathrm{H}, \mathrm{d}, J=7.4 \mathrm{~Hz}), 2.07$ $(1 \mathrm{H}, \mathrm{m}), 0.98(6 \mathrm{H}, \mathrm{d}, J=6.7 \mathrm{~Hz})$. LCMS $\left(\mathrm{ES}^{+}\right)[\mathrm{M}+\mathrm{H}]^{+} \mathrm{m} / z 231.1$.

Prototypical Procedure for the Hydrogenation of an Aryl Nitro Group to an Amine. 6-Isobutylquinolin-5-amine. A solution of 6-isobutyl-5-nitro-quinoline (286 mg, $1.42 \mathrm{mmol})$ in EtOAc (10 $\mathrm{mL}$ ) was subjected to hydrogenation conditions with $5 \% \mathrm{Pd} / \mathrm{C}$ (93 $\mathrm{mg}$ ) under a hydrogen balloon at room temperature for $6 \mathrm{~h}$. The reaction mixture was filtered through Celite, and the filtrate was concentrated to give the crude title compound $(285 \mathrm{mg}, 1.19 \mathrm{mmol}$, $92 \%)$ as a brown solid, which was used without purification. LCMS $\left(\mathrm{ES}^{+}\right)[\mathrm{M}+\mathrm{H}]^{+} \mathrm{m} / z$ 201.1.

Prototypical Procedure for the Coupling on an Aryl Amine with a Sulfonyl Chloride. 4-Bromo-N-(6-isobutylquinolin-5-yl)benzenesulfonamide (27). 5-Amino-6-isobutylquinoline (220 mg, $1.10 \mathrm{mmol}$ ) was taken up in a mixture of pyridine $(2 \mathrm{~mL})$ and DCM (3 mL); 4-bromobenzene-1-sulfonyl chloride $(337 \mathrm{mg}, 1.32 \mathrm{mmol}$ ) was added, and the reaction mixture was stirred at room temperature for 3 days. The solvent was removed under reduced pressure; the residue was partitioned with DCM and saturated aqueous sodium bicarbonate solution, and the organics were dried $\left(\mathrm{MgSO}_{4}\right)$ and concentrated to dryness. Purification by flash chromatography (0$100 \%$ EtOAc- $\mathrm{CH}_{2} \mathrm{Cl}_{2}$ ) gave the title compound $(299 \mathrm{mg}, 0.71 \mathrm{mmol}$, $65 \%)$ as a cream solid.

${ }^{1} \mathrm{H}$ NMR (DMSO- $\left.d_{6}, 500 \mathrm{MHz}\right) \delta 10.14(1 \mathrm{H}, \mathrm{s}), 8.79(1 \mathrm{H}, \mathrm{dd}, J=$ $4.2,1.6 \mathrm{~Hz}), 8.00(1 \mathrm{H}, \mathrm{d}, J=8.5 \mathrm{~Hz}), 7.93(1 \mathrm{H}, \mathrm{d}, J=8.8 \mathrm{~Hz}), 7.76$ $(2 \mathrm{H}, \mathrm{d}, J=8.6 \mathrm{~Hz}), 7.66(1 \mathrm{H}, \mathrm{d}, J=8.8 \mathrm{~Hz}), 7.52(2 \mathrm{H}, \mathrm{d}, J=8.6 \mathrm{~Hz})$, $7.34(1 \mathrm{H}, \mathrm{dd}, J=8.6,4.2 \mathrm{~Hz}), 2.50(2 \mathrm{H}, \mathrm{br} . \mathrm{s}), 1.92(1 \mathrm{H}, \mathrm{m}), 0.75$ 


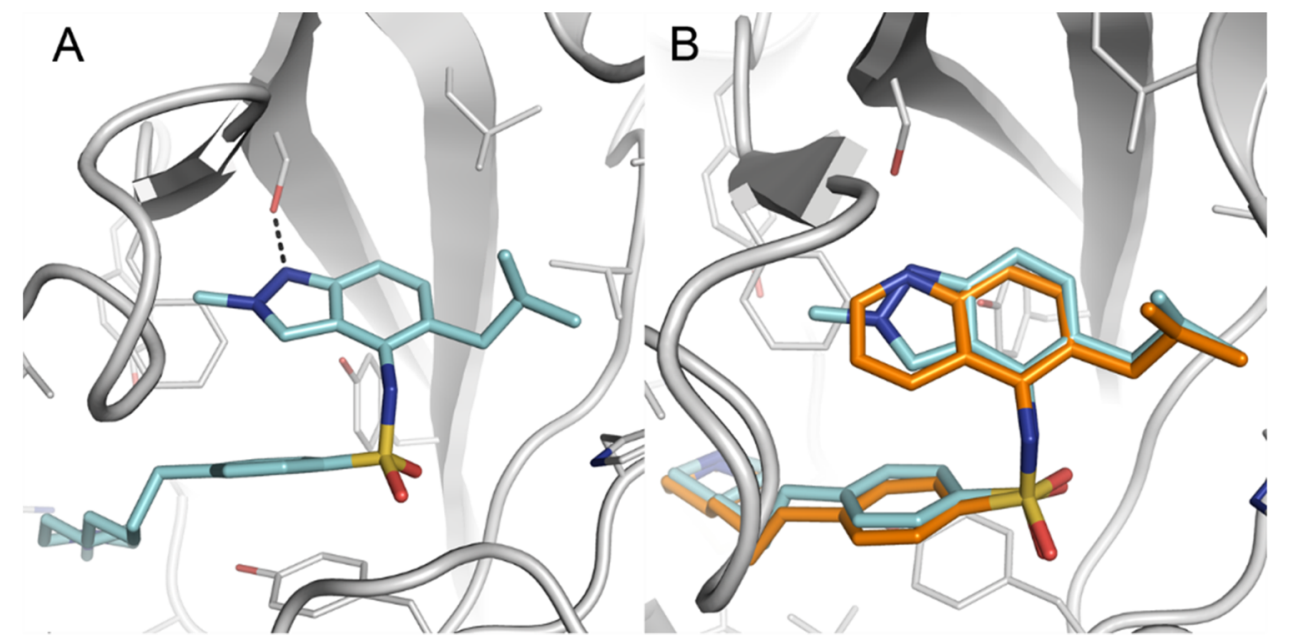

Figure 7. Crystal structure of the indazole ligand 54 bound to LmNMT:MCoA. (A) Binding mode of 54 (C atoms light blue) showing H-bond to Ser300. (B) Binding mode comparison of $\mathbf{5 4}$ with quinoline scaffold 32 (C atoms gold).

\section{Table 5. DMPK Data for Selected Compounds}

\begin{tabular}{|c|c|c|c|c|c|c|c|c|c|}
\hline cmpd & $\begin{array}{l}\text { TbNMT } \mathrm{IC}_{50} \\
(\mathrm{nM})\end{array}$ & $\begin{array}{l}H_{(\mathrm{NMT})} \mathrm{IC}_{50} \\
\end{array}$ & $\begin{array}{l}\text { T. brucei } \mathrm{EC}_{50} \\
(\mathrm{nM})\end{array}$ & $\begin{array}{l}\text { enzyme } \\
\text { selectivity }\end{array}$ & “S” & $\begin{array}{l}\text { Cli mouse microsomes } \mathrm{mL}^{-1} \\
\min ^{-1} \mathrm{~g}^{-1}\end{array}$ & $\begin{array}{l}\text { mouse } \\
\text { brain:blood ratio }\end{array}$ & $\begin{array}{c}\text { mouse PPB } \\
\left(f_{u}\right)\end{array}$ & $\begin{array}{l}\mathrm{hERG}^{a} \\
\mathrm{IC}_{50} / \mu \mathrm{M}\end{array}$ \\
\hline \multicolumn{10}{|c|}{ Quinoline Series } \\
\hline 32 & $<5$ & 250 & 19 & $>50$ & 13 & 6.2 & & & \\
\hline 34 & $<5$ & 640 & 40 & $>130$ & 16 & 6.2 & 0.8 & 0.17 & 1.3 \\
\hline 37 & 6 & 1400 & 59 & 59 & 24 & 1.8 & 0.8 & 0.093 & \\
\hline 41 & 7 & 27000 & 91 & 3900 & 300 & 1.5 & 0.8 & 0.18 & 1.6 \\
\hline \multicolumn{10}{|c|}{ Indazole Series } \\
\hline 54 & $<5$ & 230 & 5 & $>46$ & 46 & 2.9 & $<0.1$ & 0.062 & 3.7 \\
\hline 58 & $<5$ & 2500 & 31 & $>500$ & 80 & 3.7 & $<0.1$ & & 3.0 \\
\hline 60 & 5 & 12000 & 39 & 2500 & 320 & 1.4 & $<0.1$ & & 3.3 \\
\hline 62 & 7 & 4600 & 220 & 660 & 21 & 20 & & & 3.1 \\
\hline 63 & $<5$ & 190 & 26 & $>38$ & 7 & 24 & & & 5.6 \\
\hline 64 & $<5$ & 130 & 9 & $>26$ & 14 & 22 & & & 6.7 \\
\hline
\end{tabular}

${ }^{a} \mathrm{hERG}$ values were determined using IonWorks patch-clamp electrophysiology at Essen Bioscience, UK.<smiles>CC(C)Cc1ccc2nn(C)cc2c1NOc1ccc(CCCCC2CCN(C)CC2)cc1</smiles><smiles>[Y6]N1CCOC(COCCCc2ccc(S(=O)Nc3c(CC(C)C)ccc4nn(C)cc34)cc2)C1</smiles><smiles>CC(C)Cc1ccc2nn(C)cc2c1NOc1ccc(CCCOC[C@@H]2COCCN2[Na])cc1</smiles><smiles>[Y6]N1CCO[C@@H](COCCCc2ccc(S(=O)Nc3c(CC(C)C)ccc4nn(C)cc34)cc2)C1</smiles>

Figure 8. Illustration of the strategy to lower $\log \mathrm{D}$ and $\mathrm{p} K_{\mathrm{a}}$ by replacement of the piperidine moiety of $\mathbf{5 4}$ with a morpholine group.

$(6 \mathrm{H}, \mathrm{d}, J=5.5 \mathrm{~Hz})$. LCMS $\left(\mathrm{ES}^{+}\right)[\mathrm{M}+\mathrm{H}]^{+} \mathrm{m} / z$ 418.9/420.9. HRMS $\left(\mathrm{ES}^{+}\right)$: found $419.0433[\mathrm{M}+\mathrm{H}]^{+} ; \mathrm{C}_{19} \mathrm{H}_{20} \mathrm{BrN}_{2} \mathrm{O}_{2} \mathrm{~S}^{+}[\mathrm{M}+\mathrm{H}]^{+}$, requires 419.0423 .

Prototypical Procedure Coupling of an Aryl Bromide with a 9-BBN-Derived Trialkylborane under B-Alkyl Suzuki-Miyaura Conditions. N-(6-Isobutylquinolin-5-yl)-4-(4-(1-methylpiperidin-4yl)butyl)benzenesulfonamide (32). 4-(But-3-en-1-yl)-1-methylpiperidine $(61.2 \mathrm{mg}, 0.4 \mathrm{mmol})$ under argon at room temperature was treated dropwise with 9-BBN (0.5 M in THF, $0.8 \mathrm{~mL}, 0.4 \mathrm{mmol})$. The reaction mixture was heated under reflux for $1 \mathrm{~h}$. The resulting solution was then transferred into a stirred mixture of 4-bromo- $\mathrm{N}-(6-$ isobutylquinolin-5-yl)benzenesulfonamide $(82.4 \mathrm{mg}, 0.196 \mathrm{mmol})$ and potassium phosphate $(53 \mathrm{mg}, 0.25 \mathrm{mmol})$ in DMF $(2 \mathrm{~mL})$ and water $(0.6 \mathrm{~mL})$ under argon. After bubbling argon through the reaction for $5 \mathrm{~min}$ at room temperature, $\mathrm{Pd}(\mathrm{dppf}) \mathrm{Cl}_{2} \cdot \mathrm{CH}_{2} \mathrm{Cl}_{2}(16 \mathrm{mg}$, $0.02 \mathrm{mmol}, 10 \mathrm{~mol} \%)$ was added, and the reaction vessel was sealed and heated in a microwave at $90{ }^{\circ} \mathrm{C}$ for $1 \mathrm{~h}$. The reaction mixture was concentrated under reduced pressure, resuspended in $\mathrm{CH}_{2} \mathrm{Cl}_{2}$, and applied to a $2 \mathrm{~g} \mathrm{SCX}-2$ column. The column was washed with $\mathrm{CH}_{2} \mathrm{Cl}_{2}$ 


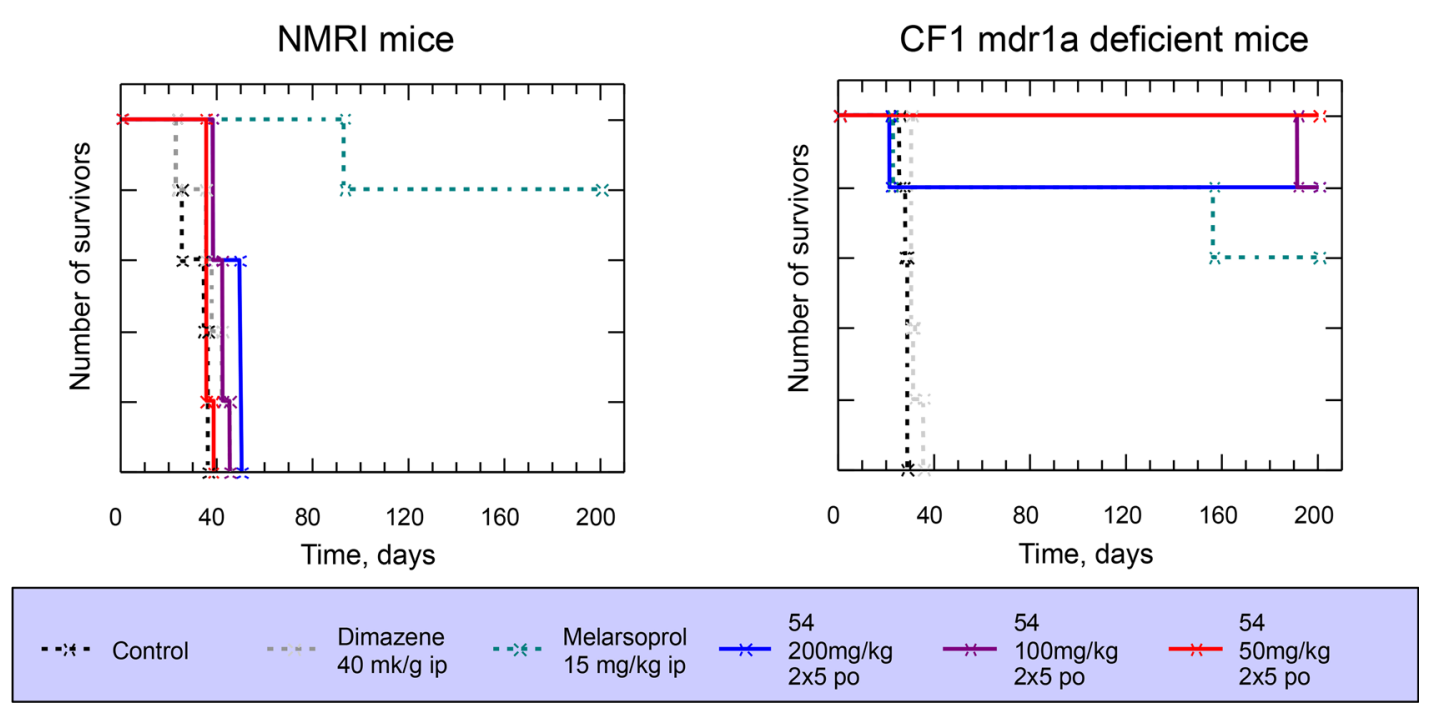

Figure 9. Kaplan-Meier survival graph for $\mathbf{5 4}$ in the NMRI and CF-1 mdrla deficient mouse infected with Trypanosoma b. brucei GVR35. Mice (five per group) were dosed with drug vehicle (orally, black), Diaminazene diaceturate (Berenil; intraperitoneally, gray), Melarsoprol (intraperitoneally, aqua), or 54 (orally, blue $(200 \mathrm{mg} / \mathrm{kg})$, purple $(100 \mathrm{mg} / \mathrm{kg})$, and red $(50 \mathrm{mg} / \mathrm{kg})$ ) for 5 days starting at day 21 following infection. Berenil and Melasoprol were administered once daily, and $\mathbf{5 4}$ was administered twice daily.

\section{Scheme 12. Compounds 65 and $66^{a}$}

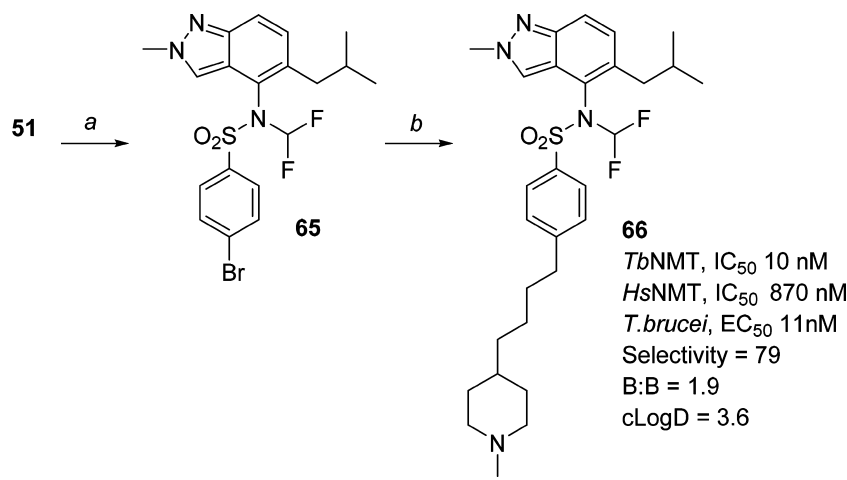

a (a) Sodium difluoroacetate, $\mathrm{K}_{2} \mathrm{CO}_{3}, \mathrm{MeCN}$; (b) 4-(but-3-en-1-yl)-1methylpiperidine, 9-BBN, THF, reflux; then $\mathrm{Pd}(\mathrm{dppf}) \mathrm{Cl}_{2}, \mathrm{~K}_{3} \mathrm{PO}_{4}$, DMF, $\mathrm{H}_{2} \mathrm{O}$.

$(10 \mathrm{~mL})$ and $10 \% \mathrm{MeOH}-\mathrm{CH}_{2} \mathrm{Cl}_{2}(20 \mathrm{~mL})$ and then eluted with a $5 \%$ mixture of $7 \mathrm{~N}$ ammonia in methanol and $\mathrm{CH}_{2} \mathrm{Cl}_{2}(10 \mathrm{~mL})$. The product-containing fractions were concentrated and purified by flash chromatography with $\mathrm{DCM} / \mathrm{MeOH} / \mathrm{NH}_{3}$ to give the title compound as an off-white solid $(55 \mathrm{mg}, 0.11 \mathrm{mmol}, 57 \%)$.

${ }^{1} \mathrm{H}$ NMR $\left(\mathrm{CDCl}_{3}, 500 \mathrm{MHz}\right) \delta 8.86(1 \mathrm{H}, \mathrm{dd}, J=4.2,1.6 \mathrm{~Hz}), 8.41$ $(1 \mathrm{H}, \mathrm{ddd}, J=8.6,1.5,0.8 \mathrm{~Hz}), 8.03(1 \mathrm{H}, \mathrm{d}, J=8.7 \mathrm{~Hz}), 7.53(2 \mathrm{H}, \mathrm{d}, J$ $=8.4 \mathrm{~Hz}), 7.50(1 \mathrm{H}, \mathrm{d}, J=8.7 \mathrm{~Hz}), 7.33(1 \mathrm{H}, \mathrm{dd}, J=8.6,4.2 \mathrm{~Hz})$, $7.23(2 \mathrm{H}, \mathrm{d}, J=8.4 \mathrm{~Hz}), 2.85(2 \mathrm{H}, \mathrm{d}, J=11.7 \mathrm{~Hz}), 2.68(2 \mathrm{H}, \mathrm{t}, J=$ $7.7 \mathrm{~Hz}), 2.28(3 \mathrm{H}, \mathrm{s}), 2.20(2 \mathrm{H}, \mathrm{d}, J=7.4 \mathrm{~Hz}), 1.90(2 \mathrm{H}, \mathrm{t}, J=6.6$ $\mathrm{Hz}), 1.82(1 \mathrm{H}, \mathrm{m}), 1.67(2 \mathrm{H}, \mathrm{d}, J=11.5 \mathrm{~Hz}), 1.61(2 \mathrm{H}$, quintet, $J=$ $7.5 \mathrm{~Hz}), 1.37-1.19(7 \mathrm{H}, \mathrm{m}), 0.80(6 \mathrm{H}, \mathrm{d}, J=6.6 \mathrm{~Hz})$. LCMS $\left(\mathrm{ES}^{+}\right)$ $[\mathrm{M}+\mathrm{H}]^{+} \mathrm{m} / z$ 494.3. HRMS $\left(\mathrm{ES}^{+}\right)$: found 494.2832 $[\mathrm{M}+\mathrm{H}]^{+}$; $\mathrm{C}_{29} \mathrm{H}_{40} \mathrm{~N}_{3} \mathrm{O}_{2} \mathrm{~S}^{+}[\mathrm{M}+\mathrm{H}]^{+}$, requires 494.2836.

$\mathrm{N}$-(5-Isobutyl-2-methyl-2H-indazol-4-yl)-4-(4-(1-methylpiperidin-4-yl)butyl)benzenesulfonamide (54). According to the procedure above, the trialkylborane was preformed with 4-but-3-enyl-1methylpiperidine $(1.02 \mathrm{~g}, 6.63 \mathrm{mmol})$ followed by Suzuki reaction with 4-bromo-N-(5-isobutyl-2-methyl-2H-indazol-4-yl)benzenesulfonamide $(51)(2.0 \mathrm{~g}, 4.74 \mathrm{mmol})$ at $100{ }^{\circ} \mathrm{C}$ for $90 \mathrm{~min}$ on a heating block. The free base was recrystallized from EtOAc to give the title compound as an off-white powder $(2.06 \mathrm{~g}, 4.14 \mathrm{mmol}$, $87 \%)$.
${ }^{1} \mathrm{H}$ NMR (DMSO- $\left.d_{6}, 500 \mathrm{MHz}\right): \delta 9.38(1 \mathrm{H}, \mathrm{br} \mathrm{s}), 7.54(2 \mathrm{H}, \mathrm{d}, J$ $=7.8 \mathrm{~Hz}), 7.52(1 \mathrm{H}, \mathrm{s}), 7.39(1 \mathrm{H}, \mathrm{d}, J=8.7 \mathrm{~Hz}), 7.32(2 \mathrm{H}, \mathrm{d}, J=7.8$ $\mathrm{Hz}), 7.04(1 \mathrm{H}, \mathrm{d}, J=8.7 \mathrm{~Hz}), 4.01(3 \mathrm{H}, \mathrm{s}), 2.73(2 \mathrm{H}, \mathrm{d}, J=11.0 \mathrm{~Hz})$, $2.66(2 \mathrm{H}, \mathrm{t}, J=7.8 \mathrm{~Hz}), 2.31(2 \mathrm{H}, \mathrm{d}, J=7.8 \mathrm{~Hz}), 2.14(3 \mathrm{H}, \mathrm{s}), 1.83$ $(2 \mathrm{H}, \mathrm{t}, J=7.8 \mathrm{~Hz}), 1.78(1 \mathrm{H}, \mathrm{m}), 1.61-1.55(4 \mathrm{H}, \mathrm{m}), 1.34-1.21$ $(4 \mathrm{H}, \mathrm{m}), 1.16-1.09(3 \mathrm{H}, \mathrm{m}), 0.73(6 \mathrm{H}, \mathrm{d}, J=6.8 \mathrm{~Hz}) .{ }^{13} \mathrm{C}$ NMR $\left(125 \mathrm{MHz}, \mathrm{CDCl}_{3}\right): \delta 149.1$ (C), $148.6(\mathrm{C}), 136.6$ (C), $130.0(\mathrm{C})$, $128.9(2 \times \mathrm{CH}), 127.3(\mathrm{CH}), 124.6(\mathrm{CH}), 124.5(\mathrm{C}), 121.4(\mathrm{C})$ $116.7(\mathrm{CH}), 56.0\left(\mathrm{CH}_{2}\right), 46.5\left(\mathrm{CH}_{3}\right), 40.3\left(\mathrm{CH}_{3}\right), 39.2\left(\mathrm{CH}_{2}\right), 36.3$ $\left(\mathrm{CH}_{2}\right), 35.8\left(\mathrm{CH}_{2}\right), 35.1(\mathrm{CH}), 32.4\left(\mathrm{CH}_{2}\right), 31.4\left(\mathrm{CH}_{2}\right), 29.5(\mathrm{CH})$, $26.3\left(\mathrm{CH}_{2}\right), 22.3\left(\mathrm{CH}_{3}\right)$. LCMS $\left(\mathrm{ES}^{+}\right)[\mathrm{M}+\mathrm{H}]^{+} \mathrm{m} / z$ 497.2. HRMS $(m / z):[\mathrm{M}+\mathrm{H}]^{+}$calcd for $\mathrm{C}_{28} \mathrm{H}_{41} \mathrm{~N}_{4} \mathrm{O}_{2} \mathrm{~S}$, 497.2945; found 497.2946.

Enzyme Inhibition Assay and Cell Viability Assay. NMT enzyme inhibition assays were carried out using a scintillation proximity assay utilizing $\left[{ }^{3} \mathrm{H}\right]$ myristoyl-coA and a peptide substrate derived from T. brucei calpain-type protease CAP5.5 as described previously. ${ }^{6}$ Assays were performed at room temperature $\left(22-23^{\circ} \mathrm{C}\right)$ in 384-well white optiplates (PerkinElmer). Each assay was performed in a $40 \mu \mathrm{L}$ reaction volume containing $30 \mathrm{mM}$ Tris buffer, $\mathrm{pH} 7.4,0.5$ mM EDTA, 0.5 mM EGTA, $1.25 \mathrm{mM}$ dithiothreitol (DTT), 0.1\% (v/ v) Triton $\mathrm{X}-100,0.125 \mu \mathrm{M}\left[{ }^{3} \mathrm{H}\right]$ myristoyl-coA (8 Curie (Ci) $\mathrm{mmol}^{-1}$ ), $0.5 \mu \mathrm{M}$ biotinylated CAP5.5, $5 \mathrm{nM}$ NMT, and various concentrations of the test compound. Test compound $(0.4 \mu \mathrm{L}$ in DMSO) was transferred to all assay plates using a Cartesian Hummingbird (Genomics Solution) before $20 \mu \mathrm{L}$ of enzyme was added to assay plates. The reaction was initiated with $20 \mu \mathrm{L}$ of a substrate mix and stopped after $15 \mathrm{~min}$ (HsNMT1) or $50 \mathrm{~min}$ (TbNMT) with $40 \mu \mathrm{L}$ of a stop solution containing $0.2 \mathrm{M}$ phosphoric acid, pH 4.0 and $1.5 \mathrm{M} \mathrm{MgCl}_{2}$ and $1 \mathrm{mg} \mathrm{ml}^{-1}$ PVT SPA beads (GE Healthcare). All reaction mix additions were carried out using a Thermo Scientific WellMate (Matrix). Plates were sealed and read on a TopCount NXT Microplate Scintillation and Luminescence Counter (PerkinElmer).

T. brucei cell viability assays were carried out as described previously. ${ }^{6}$ In brief, bloodstream T. $b$. brucei $\mathrm{s} 427$ was cultured at $37{ }^{\circ} \mathrm{C}$ in modified HMI9 medium (56 $\mu \mathrm{M}$ 1-thioglycerol was substituted for $200 \mu \mathrm{M}$ 2-mercaptoethanol) and quantified using a hemocytometer. Cell culture plates were stamped with $1 \mu \mathrm{L}$ of an appropriate concentration of test compound in DMSO followed by the addition of $200 \mu \mathrm{L}$ of trypanosome culture $\left(10^{4}\right.$ cells ml $\left.^{-1}\right)$ to each well except for one column that received media only. Culture plates of T. brucei cells were incubated at $37{ }^{\circ} \mathrm{C}$ in an atmosphere of $5 \% \mathrm{CO}_{2}$ for $69 \mathrm{~h}$ before the addition of $20 \mu \mathrm{L}$ of resazurin (final concentration, $50 \mu \mathrm{M})$. After a further $4 \mathrm{~h}$ incubation, fluorescence 
was measured (excitation $528 \mathrm{~nm}$; emission $590 \mathrm{~nm}$ ) using a BioTek flx800 plate reader.

Protein Crystallography. $L m$ NMT protein ligand complexes were determined using methods described previously. ${ }^{4,5}$ Diffraction data were measured at ESRF (beamlines ID14-1, ID41-4, and ID-29) and Diamond beamline I03. Data were integrated and scaled using either the HKL suite ${ }^{31}$ (LmNMT:4 and LmNMT:10) or XDS ${ }^{32}$ and SCALA $^{33}$ (LmNMT:18, LmNMT:32, and LmNMT:54). All structures were solved by molecular replacement as implemented in MOLREP $^{34}$ using the binary LmNMT:MCoA complex (PDB ID: $3 \mathrm{H} 5 \mathrm{Z}$ ) as a search model. Refinement and model building was carried out using REFMAC5 ${ }^{35}$ and COOT. ${ }^{36}$ Ligand coordinate files and restraints were generated using PRODRG. ${ }^{37}$ Coordinates for $L m N M T$ :ligand complexes and associated diffraction data have been deposited in the Protein Data Bank (PDB) with accession codes $6 \mathrm{GNH}, 6 \mathrm{GNS}, 6 \mathrm{GNT}, 6 \mathrm{GNU}$, and $6 \mathrm{GNV}$ for compounds 4 , $10,18,32$, and 54 , respectively.

\section{ASSOCIATED CONTENT}

\section{S Supporting Information}

The Supporting Information is available free of charge on the ACS Publications website at DOI: 10.1021/acs.jmedchem. 8 b00884.

Supplementary data table, synthetic details for compounds 4, 10,12, 13, 16, 17, 22-46, and 49-64, X-ray data collection and refinement statistics, details of DMPK experiments including intrinsic clearance (Cli) experiments, plasma protein binding experiments, plasma stability experiments, in vivo mouse studies including mouse pharmacokinetics, mouse brain penetration, rat brain penetration with and without Pgp inhibitor, HAT stage 1 mouse model of efficacy, and HAT stage 2 mouse model of efficacy(PDF)

Molecular formulas strings for compounds described in this article (CSV)

\section{AUTHOR INFORMATION}

\section{Corresponding Authors}

*(K.D.R.) Phone: +44 1382388 688; E-mail: k.read@dundee. ac.uk.

*(I.H.G.) Phone: +44 1382386 240; E-mail: i.h.gilbert@ dundee.ac.uk.

\section{ORCID}

David A. Robinson: 0000-0003-1979-5918

Ngai Mok: 0000-0002-2827-3735

Paul G. Wyatt: 0000-0002-0397-245X

Ian H. Gilbert: 0000-0002-5238-1314

Kevin D. Read: 0000-0002-8536-0130

\section{Notes}

The authors declare no competing financial interest.

\section{ACKNOWLEDGMENTS}

Funding for this work was provided by the Wellcome Trust (Grants WT077705 and WT094090 and Strategic Award WT083481). We thank Gina McKay for performing HRMS analyses, Lorna Campbell and Sandra O'Neill for performing parasite assays, and Daniel James for data management. We thank the staff at the European Synchrotron Radiation Facility (ESRF) and Diamond Light Source (DLS) for beam time and support.

\section{ABBREVIATIONS USED}

NMT, N-myristoyltransferase; T. brucei, Trpanosoma brucei; $T$. br. brucei, T. brucei. brucei; T. b. gambiense, T. brucei. gambiense; T. b. rhodensiense, T. brucei. rhodensiense; HAT, human African trypanosomiasis or sleeping sickness; CoA, Coenzyme A; MCoA, myristoyl-coenzyme A; CNS, central nervous system; TbNMT, T. brucei N-myristoyltransferase; HsNMT, human NMT; LmNMT, Leishmania major NMT; MRC-5, Medical Research Council cell strain 5; LE, ligand efficiency; LLE, Ligand-Lipophilicity Efficiency; "S”, HsNMT $\mathrm{IC}_{50} /$ T. brucei $\mathrm{EC}_{50}$; PSA, polar surface area; HBA, hydrogen bond acceptor; 9-BBN, 9-borabicyclo(3.3.1)nonane; t-Boc, tert-butoxycarbonyl; TFA, trifluoroacetic acid; THF, tetrahydrofuran; DMF, $N, N$-dimethylformamide; $\mathrm{BBB}$, blood-brain barrier; Cli, microsomal intrinsic clearance; $\mathrm{PPB}$, plasma protein binding; $\mathrm{fu}$, fraction unbound; Pgp, P-glycoprotein; hERG, human ether-a-go-go related gene; $\operatorname{cLogP}$, calculated $\log \mathrm{P} ; C_{\max }$ maximum blood concentration; $T_{\max }$ time when maximum blood concentration achieved; AUC, area under the blood concentration-time curve; SAR, structure-activity relationship; TLC, thin-layer chromatography; UV, ultraviolet light; TIC, total ion chromatogram; HPLC, high-performance liquid chromatography; LC-MS, liquid chromatography-mass spectrometry; ES, electrospray; HRMS, high-resolution mass spectrometry; eq, equivalents; EtOAc, ethyl acetate; DCM, dichloromethane; EDTA, ethylenediaminetetraacetic acid; EGTA, ethylene glycol-bis( $\beta$-aminoethyl ether)- $N, N, N^{\prime}, N^{\prime}$ tetraacetic acid; DMSO, dimethyl sulfoxide; DTT, dithiothreitol; UPLCMSMS, ultraperformance liquid-chromatography tandem mass spectrometry

\section{REFERENCES}

(1) Jacobs, R. T.; Nare, B.; Phillips, M. A. State of the art in African trypanosome drug discovery. Curr. Top. Med. Chem. 2011, 11, 12551274.

(2) Bowyer, P. W.; Tate, E. W.; Leatherbarrow, R. J.; Holder, A. A.; Smith, D. F.; Brown, K. A. N-myristoyltransferase: a prospective drug target for protozoan parasites. ChemMedChem 2008, 3, 402-408.

(3) Price, H. P.; Guther, M. L. S.; Ferguson, M. A. J.; Smith, D. F. Myristoyl-CoA:protein N-myristoyltransferase depletion in trypanosomes causes avirulence and endocytic defects. Mol. Biochem. Parasitol. 2010, 169, 55-58.

(4) Frearson, J. A.; Brand, S.; McElroy, S. P.; Cleghorn, L. A.; Smid, O.; Stojanovski, L.; Price, H. P.; Guther, M. L.; Torrie, L. S.; Robinson, D. A.; Hallyburton, I.; Mpamhanga, C. P.; Brannigan, J. A.; Wilkinson, A. J.; Hodgkinson, M.; Hui, R.; Qiu, W.; Raimi, O. G.; van Aalten, D. M.; Brenk, R.; Gilbert, I. H.; Read, K. D.; Fairlamb, A. H.; Ferguson, M. A.; Smith, D. F.; Wyatt, P. G. N-myristoyltransferase inhibitors as new leads to treat sleeping sickness. Nature 2010, 464, 728-732.

(5) Brand, S.; Cleghorn, L. A.; McElroy, S. P.; Robinson, D. A.; Smith, V. C.; Hallyburton, I.; Harrison, J. R.; Norcross, N. R.; Spinks, D.; Bayliss, T.; Norval, S.; Stojanovski, L.; Torrie, L. S.; Frearson, J. A.; Brenk, R.; Fairlamb, A. H.; Ferguson, M. A.; Read, K. D.; Wyatt, P. G.; Gilbert, I. H. Discovery of a novel class of orally active trypanocidal N-myristoyltransferase inhibitors. J. Med. Chem. 2012, $55,140-152$.

(6) Brand, S.; Norcross, N. R.; Thompson, S.; Harrison, J. R.; Smith, V. C.; Robinson, D. A.; Torrie, L. S.; McElroy, S. P.; Hallyburton, I.; Norval, S.; Scullion, P.; Stojanovski, L.; Simeons, F. R.; van Aalten, D.; Frearson, J. A.; Brenk, R.; Fairlamb, A. H.; Ferguson, M. A.; Wyatt, P. G.; Gilbert, I. H.; Read, K. D. Lead optimization of a pyrazole sulfonamide series of Trypanosoma brucei N-myristoyltransferase inhibitors: identification and evaluation of CNS penetrant compounds 
as potential treatments for stage 2 human African trypanosomiasis. J. Med. Chem. 2014, 57, 9855-9869.

(7) Brannigan, J. A.; Roberts, S. M.; Bell, A. S.; Hutton, J. A.; Hodgkinson, M. R.; Tate, E. W.; Leatherbarrow, R. J.; Smith, D. F.; Wilkinson, A. J. Diverse modes of binding in structures of Leishmania major N-myristoyltransferase with selective inhibitors. IUCrJ 2014, 1, 250-260.

(8) Hutton, J. A.; Goncalves, V.; Brannigan, J. A.; Paape, D.; Wright, M. H.; Waugh, T. M.; Roberts, S. M.; Bell, A. S.; Wilkinson, A. J.; Smith, D. F.; Leatherbarrow, R. J.; Tate, E. W. Structure-based design of potent and selective Leishmania $\mathrm{N}$-myristoyltransferase inhibitors. J. Med. Chem. 2014, 57, 8664-8670.

(9) Rackham, M. D.; Brannigan, J. A.; Rangachari, K.; Meister, S.; Wilkinson, A. J.; Holder, A. A.; Leatherbarrow, R. J.; Tate, E. W. Design and synthesis of high affinity inhibitors of Plasmodium falciparum and Plasmodium vivax N-Myristoyltransferases directed by ligand efficiency dependent lipophilicity (LELP). J. Med. Chem. 2014, 57, 2773-2788.

(10) Devadas, B.; Freeman, S. K.; Zupec, M. E.; Lu, H. F.; Nagarajan, S. R.; Kishore, N. S.; Lodge, J. K.; Kuneman, D. W.; McWherter, C. A.; Vinjamoori, D. V.; Getman, D. P.; Gordon, J. I.; Sikorski, J. A. Design and synthesis of novel imidazole-substituted dipeptide amides as potent and selective inhibitors of Candida albicans myristoylCoA:protein N-myristoyltransferase and identification of related tripeptide inhibitors with mechanism-based antifungal activity. J. Med. Chem. 1997, 40, 2609-2625.

(11) Brown, D. L.; Devadas, B.; Lu, H. F.; Nagarajan, S.; Zupec, M. E.; Freeman, S. K.; McWherter, C. A.; Getman, D. P.; Sikorski, J. A. Replacements for lysine in L-seryl-L-lysyl dipeptide amide inhibitors of Candida albicans myristoyl-CoA: Protein N-myristoyltransferase. Bioorg. Med. Chem. Lett. 1997, 7, 379-382.

(12) Devadas, B.; Zupec, M. E.; Freeman, S. K.; Brown, D. L.; Nagarajan, S.; Sikorski, J. A.; McWherter, C. A.; Getman, D. P.; Gordon, J. I. Design and synthesis of potent and selective dipeptide Inhibitors of Candida-Albicans myristoyl-Coa-Protein N-Myristoyltransferase. J. Med. Chem. 1995, 38, 1837-1840.

(13) Nagarajan, S. R.; Devadas, B.; Zupec, M. E.; Freeman, S. K.; Brown, D. L.; Lu, H. F.; Mehta, P. P.; Kishore, N. S.; McWherter, C. A.; Getman, D. P.; Gordon, J. I.; Sikorski, J. A. Conformationally constrained [p-(omega-aminoalkyl)phenacetyl]-L-seryl-L-lysyl dipeptide amides as potent peptidomimetic inhibitors of Candida albicans and human myristoyl-CoA:protein $\mathrm{N}$-myristoyl transferase. J. Med. Chem. 1997, 40, 1422-1438.

(14) Sikorski, J. A.; Devadas, B.; Zupec, M. E.; Freeman, S. K.; Brown, D. L.; Lu, H. F.; Nagarajan, S.; Mehta, P. P.; Wade, A. C.; Kishore, N. S.; Bryant, M. L.; Getman, D. P.; McWherter, C. A.; Gordon, J. I. Selective peptidic and peptidomimetic inhibitors of Candida albicans myristoylCoA:protein N-myristoyltransferase: A new approach to antifungal therapy. Biopolymers 1997, 43, 43-71.

(15) Ebiike, H.; Masubuchi, M.; Liu, P. L.; Kawasaki, K.; Morikami, K.; Sogabe, S.; Hayase, M.; Fujii, T.; Sakata, K.; Shindoh, H.; Shiratori, Y.; Aoki, Y.; Ohtsuka, T.; Shimma, N. Design and synthesis of novel benzofurans as a new class of antifungal agents targeting fungal N-myristoyltransferase. Part 2. Bioorg. Med. Chem. Lett. 2002, 12, 607-610.

(16) Kawasaki, K.; Masubuchi, M.; Morikami, K.; Sogabe, S.; Aoyama, T.; Ebiike, H.; Niizuma, S.; Hayase, M.; Fujii, T.; Sakata, K.; Shindoh, H.; Shiratori, Y.; Aoki, Y.; Ohtsuka, T.; Shimma, N. Design and synthesis of novel benzofurans as a new class of antifungal agents targeting fungal N-myristoyltransferase. Part 3. Bioorg. Med. Chem. Lett. 2003, 13, 87-91.

(17) Masubuchi, M.; Ebiike, H.; Kawasaki, E.; Sogabe, S.; Morikami, K.; Shiratori, Y.; Tsujii, S.; Fujii, T.; Sakata, K.; Hayase, M.; Shindoh, H.; Aoki, Y.; Ohtsuka, T.; Shimma, N. Synthesis and biological activities of benzofuran antifungal agents targeting fungal $\mathrm{N}$ myristoyltransferase. Bioorg. Med. Chem. 2003, 11, 4463-4478.

(18) Masubuchi, M.; Kawasaki, K.; Ebiike, H.; Ikeda, Y.; Tsujii, S.; Sogabe, S.; Fujii, T.; Sakata, K.; Shiratori, Y.; Aoki, Y.; Ohtsuka, T.; Shimma, N. Design and synthesis of novel benzofurans as a new class of antifungal agents targeting fungal N-myristoyltransferase. Part 1 . Bioorg. Med. Chem. Lett. 2001, 11, 1833-1837.

(19) Yamazaki, K.; Kaneko, Y.; Suwa, K.; Ebara, S.; Nakazawa, K.; Yasuno, K. Synthesis of potent and selective inhibitors of Candida albicans $\mathrm{N}$-myristoyltransferase based on the benzothiazole structure. Bioorg. Med. Chem. 2005, 13, 2509-2522.

(20) Ebara, S.; Naito, H.; Nakazawa, K.; Ishii, F.; Nakamura, M. FTR1335 is a novel synthetic inhibitor of Candida albicans Nmyristoyltransferase with fungicidal activity. Biol. Pharm. Bull. 2005, 28, 591-595.

(21) Berthiaume, L. G.; Beauchamp, E.; Perinpanaygam, C. M. A.; Yap, C. Synthetic Lethality and the Treatment of Cancer Deficient in NMT2 Comprising an $\mathrm{N}$-myristoyltransferase (NMT) Inhibitor. WO 2013013302, 2013.

(22) Gelb, M. H.; Van Voorhis, W. C.; Buckner, F. S.; Yokoyama, K.; Eastman, R.; Carpenter, E. P.; Panethymitaki, C.; Brown, K. A.; Smith, D. F. Protein farnesyl and N-myristoyl transferases: piggy-back medicinal chemistry targets for the development of antitrypanosomatid and antimalarial therapeutics. Mol. Biochem. Parasitol. 2003, 126, $155-163$.

(23) Price, H. P.; Goulding, D.; Smith, D. F. ARL1 has an essential role in Trypanosoma brucei. Biochem. Soc. Trans. 2005, 33, 643-645.

(24) Hopkins, A. L.; Groom, C. R.; Alex, A. Ligand efficiency: a useful metric for lead selection. Drug Discovery Today 2004, 9, 430431.

(25) Leeson, P. D.; Springthorpe, B. The influence of drug-like concepts on decision-making in medicinal chemistry. Nat. Rev. Drug Discovery 2007, 6, 881-890.

(26) Miyaura, N.; Ishiyama, T.; Sasaki, H.; Ishikawa, M.; Sato, M.; Suzuki, A. Palladium-catalyzed intermolecular and intramolecular cross-coupling reactions of B-alkyl-9-borabicyclo[3.3.1] nonane derivatives with 1-halo-1-alkenes or haloarenes - syntheses of functionalized alkenes, arenes, and cycloalkenes via a hydroboration coupling sequence. J. Am. Chem. Soc. 1989, 111, 314-321.

(27) Chemler, S. R.; Trauner, D.; Danishefsky, S. J. The B-alkyl Suzuki-Miyaura cross-coupling reaction: development, mechanistic study, and applications in natural product synthesis. Angew. Chem., Int. Ed. 2001, 40, 4544-4568.

(28) Jamieson, C.; Moir, E. M.; Rankovic, Z.; Wishart, G. Medicinal chemistry of hERG optimizations: Highlights and hang-ups. J. Med. Chem. 2006, 49, 5029-5046.

(29) Waring, M. J.; Johnstone, C. A quantitative assessment of hERG liability as a function of lipophilicity. Bioorg. Med. Chem. Lett. 2007, 17, 1759-1764.

(30) Lankas, G. R.; Cartwright, M. E.; Umbenhauer, D. Pglycoprotein deficiency in a subpopulation of CF-1 mice enhances avermectin-induced neurotoxicity. Toxicol. Appl. Pharmacol. 1997, $143,357-365$.

(31) Otwinowski, Z.; Minor, W. Processing of X-ray Diffraction Data Collected in Oscillation Mode. Methods Enzymol. 1997, 276, 307326.

(32) Kabsch, W. Integration, scaling, space-group assignment and post-refinement. Acta Crystallogr., Sect. D: Biol. Crystallogr. 2010, 66, $133-144$.

(33) Evans, P. Scaling and assessment of data quality. Acta Crystallogr., Sect. D: Biol. Crystallogr. 2006, 62, 72-82.

(34) Vagin, A.; Teplyakov, A. Molecular replacement with MOLREP. Acta Crystallogr., Sect. D: Biol. Crystallogr. 2010, 66, 2225.

(35) Murshudov, G. N.; Skubak, P.; Lebedev, A. A.; Pannu, N. S.; Steiner, R. A.; Nicholls, R. A.; Winn, M. D.; Long, F.; Vagin, A. A. REFMAC5 for the refinement of macromolecular crystal structures. Acta Crystallogr., Sect. D: Biol. Crystallogr. 2011, 67, 355-367.

(36) Emsley, P.; Cowtan, K. Coot: model-building tools for molecular graphics. Acta Crystallogr., Sect. D: Biol. Crystallogr. 2004, 60, 2126-2132.

(37) Schuttelkopf, A. W.; van Aalten, D. M. PRODRG: a tool for high-throughput crystallography of protein-ligand complexes. Acta Crystallogr., Sect. D: Biol. Crystallogr. 2004, 60, 1355-1363. 